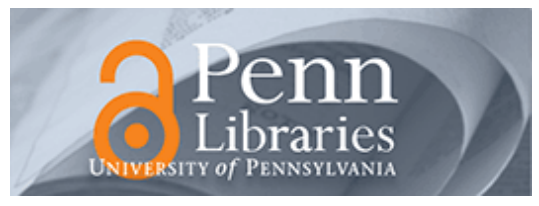

University of Pennsylvania

ScholarlyCommons

Management Papers

Wharton Faculty Research

8-2004

\title{
What Do Entrepreneurs Pay for Venture Capital Affiliation?
}

David H. Hsu

University of Pennsylvania

Follow this and additional works at: https://repository.upenn.edu/mgmt_papers

Part of the Business Administration, Management, and Operations Commons

\section{Recommended Citation}

Hsu, D. H. (2004). What Do Entrepreneurs Pay for Venture Capital Affiliation?. The Journal of Finance, 59 (4), 1805-1844. http://dx.doi.org/10.1111/j.1540-6261.2004.00680.x

This paper is posted at ScholarlyCommons. https://repository.upenn.edu/mgmt_papers/29

For more information, please contact repository@pobox.upenn.edu. 


\title{
What Do Entrepreneurs Pay for Venture Capital Affiliation?
}

\author{
Abstract \\ This study empirically evaluates the certification and value-added roles of reputable venture capitalists \\ (VCs). Using a novel sample of entrepreneurial start-ups with multiple financing offers, I analyze financing \\ offers made by competing VCs at the first professional round of start-up funding, holding characteristics \\ of the start-up fixed. Offers made by VCs with a high reputation are three times more likely to be \\ accepted, and high-reputation VCs acquire start-up equity at a $10-14 \%$ discount. The evidence suggests \\ that VCs' "extra-financial" value may be more distinctive than their functionally equivalent financial capital. \\ These extra-financial services can have financial consequences. \\ Disciplines \\ Business Administration, Management, and Operations
}




\title{
What Do Entrepreneurs Pay for Venture Capital Affiliation?
}

\author{
DAVID H. HSU*
}

Forthcoming, Journal of Finance

\footnotetext{
${ }^{*}$ The Wharton School, University of Pennsylvania. Respondents to the MIT Sloan Financing New High-Tech Ventures Survey made this project possible. I would like to thank Joshua Gans, Rick Green (the editor), Thomas Hellmann, Steve Kaplan, Augustin Landier, Josh Lerner, and especially Scott Stern and an anonymous referee, for supplying helpful comments and suggestions. I thank seminar participants at Boston University, Carnegie Mellon, Case Western, Columbia, Harvard, INSEAD, University of Maryland, the MIT Organizational Economics lunch, Michigan, the NBER Productivity lunch, National University of Singapore, New York University, Stanford, University of Toronto, University of Texas, Washington University, Wharton, and the 2002 Yale Conference on Entrepreneurship, Venture Capital and Initial Public Offerings for interesting comments and discussions. Jaimie Lien provided excellent research assistance. Funding for this project from the Wharton Management Department, the MIT Entrepreneurship Center and the MIT Center for Innovation in Product Development through NSF Cooperative Agreement EEC-9529140 is gratefully acknowledged.
} 


\begin{abstract}
This study empirically evaluates the certification and value-added roles of reputable venture capitalists (VCs). Using a novel sample of entrepreneurial startups with multiple financing offers, I analyze financing offers made by competing VCs at the first professional round of start-up funding, holding characteristics of the start-up fixed. Offers made by VCs with a high reputation are three times more likely to be accepted, and high-reputation VCs acquire start-up equity at a 10 to $14 \%$ discount. The evidence suggests that VCs' "extra-financial" value may be more distinctive than their functionally equivalent financial capital. These extra-financial services can have financial consequences.
\end{abstract}


A central issue for early-stage high-tech entrepreneurs is obtaining external resources when the assets of their start-up are intangible and knowledge-based. Particularly for entrepreneurs without an established reputation, convincing external resource providers such as venture capitalists to provide financial capital may be challenging. The literature contains two main lines of research for overcoming this problem. One research stream has concentrated on designing institutional structures to permit financing early stage ventures. This contractual- and monitoring-based approach is aimed at solving potential agency problems between investors and entrepreneurs (e.g., Admati and Pfleiderer (1994), Lerner (1995), Hellmann (1998), Kaplan and Strömberg (2001, 2002, and 2003)). A second research stream has suggested that when the quality of a start-up cannot be directly observed, external actors rely on the quality of the startup's affiliates as a signal of the start-up's own quality (e.g., Megginson and Weiss (1991), Biglaiser (1993), and Stuart, Hoang, and Hybels (1999)). This certification-based approach may help legitimate start-ups and entrepreneurs without a prior track record.

While the first research stream emphasizes the venture capitalist's problem (designing the appropriate mechanisms), the second highlights the entrepreneur's problem more directly (affiliating with highly reputable partners), and serves as an antecedent to this study. VC certification value, together with their value-added services such as recruiting executive managers (Hellmann and Puri (2002)), have led analysts in the descriptive literature to write: "It is far more important whose money you get [as an entrepreneur] than how much you get or how much you pay for it" (Bygrave and Timmons (1992, p. 208)) and "From whom you raise capital is often more important than the terms" (Sahlman (1997, p. 107)). These views clearly indicate that VCs have different value-added potential and that venture capital represents more than strict financial capital to entrepreneurs. In contrast, the extant academic literature has not emphasized $\mathrm{VC}$ heterogeneity, implicitly treating VCs as one uniform class so that reputation differences among VCs are obscured (see Gompers (1996) and Kaplan and Schoar (2003) for exceptions). As well, whereas much of the previous literature has concentrated on the benefits to certification (e.g., Megginson and Weiss (1991), and Stuart, Hoang, and Hybels (1999)), the costs of affiliating with prominent actors have not been systematically analyzed empirically. For example, the prescriptive advice to start-up entrepreneurs of affiliating with the highest status partner possible (Stuart, Hoang, and Hybels) seems strong given that calculations of returns to such action that do not take into account the costs of affiliation may be overstated. Indeed, 
demand for affiliation with reputable actors is likely to vary with the cost of such association. More generally, because affiliation with reputable partners confers performance benefits, such association cannot be freely accessed, for otherwise certification agents would not have incentives to invest in acquiring a reputation in the first place (Shapiro (1983)). ${ }^{1}$

Consequently, this article explores two interlinked questions: Is there a market for affiliation with reputable partners? If so, what are the prices for such affiliation? Entrepreneurial demand for affiliation with venture capitalists provides an excellent empirical setting to explore these questions for two reasons. First, because VCs can certify and start-ups need to be certified, the exchange nature of the relationship provides a natural marketplace for affiliation. Secondly, due to the tremendous increase in the supply of venture capital in the second half of the $1990 \mathrm{~s},{ }^{2}$ the situation of "money chasing deals" makes observing a menu of price offers by VCs with varying reputation more likely — a necessary condition for identifying the market for affiliation.

The empirical analysis investigates proxies for $\mathrm{VC}$ reputation which explain the variation in offers accepted and valuations offered to start-ups at a point in time, while holding start-up characteristics fixed. To implement this methodology, I developed a novel, hand-collected dataset of 148 financing offers (both those accepted and declined) made to a group of 51 early stage high-tech start-ups. The estimated effects are both statistically and economically significant. A financing offer from a high reputation VC is approximately three times more likely to be accepted by an entrepreneur. As well, highly reputable VCs acquire start-up equity at a 10 to $14 \%$ discount.

The empirical results suggest that entrepreneurs are willing to forego offers with higher valuations in order to affiliate with more reputable venture capitalists. These results are consistent with the idea that venture capitalists act as more than strict financial intermediaries, placing funds from investors to capital-constrained start-ups. If this were not the case, we might expect entry by suppliers of entrepreneurial finance to equilibrate prices for start-up equity across offers to a given firm. However, if VCs differed in the bundle of services and certification they provide to their portfolio companies, which might be thought of as "extra-financial" VC

\footnotetext{
${ }^{1}$ The extant research on the market for certification has only established general bounds. Statements on the supply of certification have generally been limited to an acknowledgment that such suppliers will not want to provide affiliation to entities that will damage their reputations (Podolny (1993)). Likewise, on the demand side, screening theories would argue that only those organizations that will benefit most from certification will accept the terms of a stringent supply contract (e.g., Kaplan and Strömberg (2001, 2003)).

${ }^{2}$ Disbursements to start-ups from VCs, which totaled just $\$ 665 \mathrm{M}$ in 1980 and $\$ 2.3 \mathrm{~B}$ in 1990, skyrocketed to over $\$ 100 B$ in 2000 (National Venture Capital Association Yearbook (2001)).
} 
functions, then prices for affiliation might differ. This implies that the $\mathrm{VC}$ information network and its certification value may be more distinctive than their financial capital, and so these extrafinancial VC functions can have financial consequences - namely, the price at which VCs are able to acquire equity in a given start-up. Indeed, this view is consistent with the stylized fact that VCs experience substantial inter-industry variation in financial performance (Kaplan and Schoar (2003)). Consequently, future research exploring variation within the VC industry, especially as it relates to organizational performance, would be interesting.

The remainder of this paper is organized as follows: Section I discusses the relevant prior literature and derives hypotheses about the entrepreneurial market for VC affiliation. Section II describes the methodology and data used to test these hypotheses. Empirical results are discussed in Section III, while a final section concludes with a discussion of the implications and limitations of the study.

\section{Literature and Hypothesis Development}

This section starts with a discussion of reputation as an economic good, develops the notion of a market for affiliation, and concludes with hypotheses about the demand for $\mathrm{VC}$ affiliation by early stage start-ups.

\section{A. Reputation and Affiliation as Economic Goods}

Reputation, which results from prior experience and performance, has been identified as an economically important asset that can generate future rents when information among actors is asymmetric (e.g., Shapiro (1983) and Biglaiser (1993)). Starting with Spence (1974), there has been a sizeable theoretical literature on the phenomenon of actors without an established reputation signaling quality to the external market. For example, Bagwell and Bernheim (1996) present a theory of Veblen effects in which people engage in conspicuous consumption because material displays of relative wealth signal social status.

A related strand of research suggests that performance benefits can be realized by the reputable producer's affiliates through a process of certification. This phenomenon has been examined in the context of reputable investment banks and venture capitalists and the pricing of initial public offerings (Beatty and Ritter (1986) and Megginson and Weiss (1991)). These 
agents can credibly stake their reputations on the claim that the IPOs they back are not overpriced as a result of their repeated interactions with external parties.

More generally, for a certification to be effective, it must fulfill three conditions: (1) The certifying agent must have reputational capital at stake that would be compromised with an invalid certification; (2) the certifying agent's reputational capital must exceed the largest onetime wealth transfer from a mis-certification; and (3) the certified target must face a cost of leasing the reputational capital of the certifying agent (Booth and Smith (1986)). This final condition is an important one for insuring that the certifying agent would have the proper incentives to invest in its own reputation. Unfortunately, it has not received much empirical attention; consequently it is this market for "leasing" reputational capital (and the associated prices for doing so) that forms the core of the empirical analysis in this paper.

Venture capitalists meet the three previously stated criteria of certifying agents and can therefore be suppliers of certification (Megginson and Weiss (1991)). Start-ups, especially those in the early stages, often do not have an established reputation, and may therefore demand certification. Individual start-ups do not have repeated interactions with organizations associated with exiting an investment (e.g., acquiring firms or investment bankers), and therefore do not build a reputation in this community. In the market for affiliation, the supply of financial capital (and attention) from reputable venture capitalists is limited. Furthermore, there is heterogeneity in the demand for such association, because entrepreneurs have both different initial endowments of resources and reputation, as well as different expectations of the marginal benefit of affiliation.

The market for affiliation is reflected in prices offered by VCs and accepted by entrepreneurs in the exchange of start-up equity for venture capital. Moreover, the price that VCs pay to acquire start-up equity is important to both entrepreneurs and VCs. For entrepreneurs, the valuation they receive at a round of financing determines how much equity is sold for a given capital infusion, and may have corporate control implications. Venture capitalists also care about price. In a liquidity event, VCs earn the difference between the share price at that time and the price they paid to acquire the start-up's equity. Interestingly, Megginson and Weiss forward the notion that entrepreneurs may have to compromise valuation to "pay" for VC certification: "one of the services that entrepreneurial firms purchase with VC funding is easier access to capital markets and the ability of venture capitalists to reduce asymmetrical information in the offering 
process" (1991, p. 883; emphasis added). Left unanswered, however, is the purchase price startups pay to access reputable VCs. The next section therefore addresses the question of what makes a VC reputable.

\section{B. What Makes VCs Reputable?}

The business press and descriptive literature have characterized simple monetary capital infusion as commodity-like in the early-stage start-up process, and VCs have sought to differentiate themselves by the quality of business services and reputational capital they bring to their portfolio companies (e.g., New York Times (2000)). Some VCs argue that while start-ups might give up a larger equity stake in their company for a given capital infusion by a more experienced $\mathrm{VC}$, the entrepreneur's remaining stake in his company is more valuable ex post as a result of the venture capitalist's value-added services. These services include business referrals, extensive mentoring, and financial assistance (MacMillan, Kulow, and Khoylian (1989)), which may be particularly important for early-stage start-ups (Roberts (1991)). Entrepreneurs seem to accept the reasoning that there is value in being associated with experienced and connected VCs:

\footnotetext{
Venture funding is available from many sources. Entrepreneurs choose a lead venture partner to tap into practical experience, contacts, and reputations. "The money is all the same," says Louis Volpe, president of Arrowpoint Communications. "But what type of additional value do you get? With Matrix Ventures, you get experienced people and a good network in telecom." Those intangibles can make the difference in landing a key early customer, attracting top caliber employees, and lining up the best IPO underwriters. The experience can make a real difference driving a brand new company in the right direction fast. (Boston Globe (2000, p. D1).
}

Therefore, as a venture capitalist gains more investment experience in a particular industrial sector, he or she is more likely to acquire the expertise needed to help start-ups in their portfolio acquire resources for successful development, which is a powerful contributor to VC reputation. Investment experience also accords with Gompers' (1996) age proxy for VC reputation. Each additional investment extends the VC's information network, either acquiring important social contacts and/or gaining experience in effectively structuring deals or monitoring entrepreneurs in the industrial sector (Sorenson and Stuart (2001)). For example, Kleiner Perkins Caufield \& Byers, a prominent venture capital firm, claims to facilitate interorganizational cooperation among its network of portfolio companies by "brokering" strategically important 
information among them. As evidence, the firm claims that there are over 100 strategic alliances among its portfolio companies, and the firm's web site (www.kpcb.com) notes:

\begin{abstract}
We borrow the term "keiretsu" from Japan's powerful networks of companies. However, unlike Japan, Kleiner's keiretsu is a particularly western, entrepreneurial, loosely coupled web of relationships. Kleiner doesn't control any ventures: they're each independent, run by strong, outstanding entrepreneurs. There's no central controlling bank, or interlocking board of directors. But the executives in the KPCB Keiretsu often share experiences, insight, knowledge and information. This network, comprised of more than 175 companies and thousands of executives, has proven to be an invaluable tool to entrepreneurs in both emerging and developing companies.
\end{abstract}

Lindsey (2002) provides empirical support for this VC "keiretsu" phenomenon. Indeed, the VC information brokerage role can be particularly important to start-up development since these early stage private firms face imperfect markets for information (Aoki (2000)). Thin markets for information arise both because start-ups are secretive in order to protect their competitive position, and because there may be few alternate channels outside of a trusted third party for information dissemination.

In addition, VCs acting as information brokers may assist a start-up in business development in different ways depending on the stage of the enterprise. In the earlier stages, VCs may help in recruiting senior executive officers (Gorman and Sahlman (1989) and Hellmann and Puri (2002)) and in striking strategic alliances (Stuart, Hoang, and Hybels (1999)). In the later stages of start-up development, VCs may help assemble additional funds and/or achieve liquidity. This may be done through hiring talented investment bankers (Barry et al. (1990) and Megginson and Weiss (1991)) or in locating merger or acquisition partners (Gans, Hsu, and Stern (2002)). Because these resources are reinforced by the VC's investment experience in the start-up's industrial sector, entrepreneurial demand for $\mathrm{VC}$ affiliation should be increasing in the VC's industry deal experience. The dual hypotheses to be tested are therefore: (a) Offers made by more reputable VCs are more likely to be accepted, and (b) the price that entrepreneurs pay in the market for affiliation is inversely associated with VC reputation.

\title{
II. Methodology and Data
}

\section{A. Methodology}

To test these hypotheses, I use a method drawn from Stern (2000) in collecting data on the bundle of offers - both accepted and declined - made to start-ups for financing the first 
professional round. This methodology, by taking an offer as the unit of analysis, is well suited to studying the market for affiliation, because examining multiple price observations associated with venture capitalists of varying reputation for a given start-up in effect traces out a demand curve for affiliation. ${ }^{3}$ Start-up firm effects can be held constant in examining valuation differences across financing offers, thus mitigating the problem of unobserved heterogeneity. Consequently, the empirical focus can shift to examining the role of differences in $\mathrm{VC}$ characteristics.

The empirical models estimate two equations using a financing offer from the multipleoffers dataset as the unit of analysis. The likelihood that an offer is accepted is modeled as:

$$
\operatorname{Pr}(\text { Offer accepted }=1)=F(\text { VC Reputation, Valuation, Controls }) \text {. }
$$

This offer acceptance equation is estimated using fixed effects logit models. The valuation equation is modeled as follows, and is estimated using fixed effects OLS regressions:

Valuation $=F($ VC Reputation, Controls $)$.

In implementing this method, it is important to study early-stage financing rounds. Earlystage investors can weigh heavily in shaping the identity of subsequent investors (often through referrals or by virtue of their reputation). As well, earlier rounds of financing are usually associated with more technical and demand uncertainty. As a result, conventional valuation methods are difficult to apply to young firms with intangible assets, and so valuations of earlystage start-ups are subject to a great deal of negotiation (rather than straightforward calculation). The resulting heterogeneity in prices for association with disparate VCs (which themselves vary in reputation) is an important feature of early-stage funding rounds that help identify the market for affiliation.

This section describes both the details of the data collection process and the data used to test the key hypothesis. Before doing so, however, it is useful to address two issues: (1) Potential biases resulting from a simple cross-sectional analysis, and (2) data collection challenges associated with employing the proposed methodology. Regarding the first issue, unobserved or mismeasured start-up qualities correlated with the price VCs pay for equity, such as differences in the demand for affiliation with reputable VCs, may bias cross-sectional estimates.

\footnotetext{
${ }^{3}$ To my knowledge, the incidence of start-ups receiving multiple financing offers has been investigated only by Smith (1999) who reports that $71 \%$ of the responding companies in his survey received more than one financing offer. While the rate of multiple offers is interesting in its own right, the current study instead uses multiple financing offer events to identify the market for affiliation.
} 
Furthermore, there may be unobserved selection processes matching start-ups with VCs. Without detailed controls for such processes, cross-sectional estimates may be biased in a way sensitive to the sampling scheme.

To collect data on a start-up's financing offers is a challenge in itself, since early-stage entrepreneurs are typically (and rightfully) reluctant to disclose information that might compromise their strategic position (Gompers and Lerner (1999) and Hellmann and Puri (2000)). In addition, VC market consulting companies do not collect data on the bundle of financing offers received by start-ups. Consequently, obtaining the set of declined financing offers (rather than assembling a matched comparable, for example) requires asking entrepreneurs themselves for the sensitive information. I do so through a survey instrument. While designing and administering the survey was a labor-intensive process, few substitutes exist to gather detailed information about (1) the founding and organization of the start-up, (2) the VCs offering to invest in the start-up, and (3) the prices that were offered. A brief section describing institutional details about the sampled start-ups precedes a discussion about the data.

\section{A.1. The MIT E-Lab Program}

The MIT Entrepreneurship Program offers a semester-long class, "Entrepreneurship Laboratory" ("E-Lab"), which assembles teams of MIT and Harvard graduate students to study specific business-related issues at actual start-ups. In exchange for a complimentary business development analysis done by graduate students, the E-Lab firms' senior executive officers commit to allocating a certain amount of time and effort to interacting with the students. E-Lab began in 1995 and approximately 300 start-up companies had applied to participate in the program by the summer of 2000. Far more companies apply for the program, however, than the supply of student teams can accommodate.

In order to qualify for E-Lab, the start-up has to meet two criteria: (1) Its headcount must be less than approximately 35 at the time of entering the program, and (2) it must have completed a Series A round of investment. This group of start-ups is an attractive one to survey for two reasons. First, the sample includes funded, early-stage start-ups that were not selected for any qualities related to the price that VCs paid for their equity. Second, because of the MIT Entrepreneurship Program affiliation, they may be more inclined to participate in this research study. 


\section{B. Data}

The empirical approach requires measures of $\mathrm{VC}$ reputation from firms offering to invest in the sample of E-Lab firms, as well as information about the offers themselves. The survey instrument (see the appendix) collects this information using a variety of measures, such as the entrepreneur's perceived reputation ranking of investors from which it received a financing offer. More objective data about the VC's reputation (e.g., investment experience in each high-tech industrial segment) were collected from the Venture Economics database through Securities Data Corporation/Thomson Financial.

\section{B.1. The Financing New High-Tech Ventures Survey}

After pre-testing the survey with entrepreneurs (both those contemporaneously undergoing the Series A financing process and those who had already gone through it), VCs, academics, and intellectual property attorneys, I mailed the survey to the population of approximately 300 E-Lab companies. I then placed telephone calls to follow up with informants. The data were collected over the phone over five months starting July 15, 2000. Respondents to the survey were typically a founder and/or a person who knew the details of a firm's start-up and financing history (frequently this was one of the following senior executive officers: a CEO, CTO, and/or CFO).

Nearly half of the companies in the E-Lab population responded to the survey. Nonrespondents seemed randomly mixed between those without time to participate in the survey and those (to a lesser extent) unwilling to participate in the study. Formal tests of differences between observables on the two samples are difficult, however, due to the data constraints on the firms not in the sample. Indeed, many of the firms in the E-Lab population were not yet listed in venture capital industry consulting firm databases.

The survey responses yielded a total of 246 offers to 149 start-ups. While 98 of these start-ups received a single financing offer, 51 of them received more than one offer for financing their first professional round. The average start-up receiving multiple offers averaged almost three offers each, resulting in 148 offers made to this set of companies.

As an overview of the entire sample, Table I (Panels A and B) reports the age distribution of start-ups in the sample, together with the distribution of offers received by the sample of E- 
Lab start-ups. The empirical puzzle in these data is that only $43 \%$ of the start-ups among those receiving multiple offers accepted their best financial offer. Moreover, the start-ups not accepting their most generous financial offer left a considerable amount of value "on the table," amounting to $\$ 173.9 \mathrm{M}$ in aggregate pre-money valuation. This was calculated as the sum of the differences between their best financial offer and the accepted offer. For the group of multiple offer firms declining their best financial offer, the foregone pre-money value as a fraction of the accepted offer ranged from a low of $3.6 \%$ to a high of $217 \%$, with an average of $33.2 \%$ for the sample. This descriptive interpretation of the data, of course, would be different if the overall sample of single and multiple offers were considered, as shown in Table I.

\section{[Insert TABLE I around here]}

Panel B of Table I also describes the means of a wide range of start-up characteristics, broken out by the number of offers received. These characteristics include start-up founding year; Series A financing year; number of employees prior to Series A funding; revenues from

first year operations; patent applications and grants; industrial representation; and geographic location. The average start-up was founded in the first half of 1997 and received its Series A funding just 14 months later (over $80 \%$ of the start-ups in the dataset received Series A funding between 1998 and 2000). Prior to receiving this funding round, the average start-up in the sample employed 10 people and had about $\$ 0.27 \mathrm{M}$ in revenues from first-year operations. As well, by the end of 2000, the typical start-up had applied for 5.4 patents and had received 1.2 patent grants. A high proportion of the start-ups, 74\%, were located in Massachusetts, which may not be surprising given the nature of the E-Lab program (by comparison, 53\% of the accepted VC offers were from Massachusetts-based VC firms). Additionally, 13\% of the start-ups in the sample were located in California (15\% of the accepted VC offers were from California-based VC firms).

The industrial representation of the E-Lab start-ups in the sample is fairly typical of the broader set of industries funded by venture capitalists over the same time period (the average ELab firm in the sample received Series A funding in the middle of 1998). Of the sampled companies, $26 \%$ are in Internet services, $17 \%$ are in Internet infrastructure, and 5\% are in Internet retailing. The software sector comprises about $16 \%$ of the sample, while computer hardware represents $6 \%$ of the sample. Communications and health sciences (biotechnology and medical devices) each comprise $10 \%$ of the sample, respectively. This distribution of firms 
seems to mirror the overall financing trends by VCs from 1997 to 2000. For example, according to Venture Economics, in 1999, 43\% of VC disbursements went to Internet-based start-ups, and $57 \%$ of VC funds in the first three quarters of 2000 were invested in that sector.

While Panel B of Table I presents the conditional means of the observable start-up characteristics by the number of offers received, it is difficult to tell whether statistical differences exist. Panel $\mathrm{C}$ therefore compares sampled start-ups receiving single offers with those receiving multiple offers via $t$-tests of equality of means. The results reveal that the startups' qualities between the single versus multiple-offers subsamples were statistically the same between the groups.

Panel D presents similar tests for the subsamples of VC characteristics. While these figures reflect accepted offers and are likely the result of a bargaining process between entrepreneurs and $\mathrm{VCs}$, it is likely that the multiple-offers subsample contains the better deals (with higher pre-money valuations, more funding offered, and greater interest from more experienced $\mathrm{VCs})$.

In order to use the start-up fixed effects methodology previously described, only the set of firms receiving multiple financing offers is analyzed in the remaining empirical tables. While selection issues as a result of this empirical strategy may be of concern, the finding that start-up characteristics are statistically the same across recipients of single- and multiple-financing offers is reassuring. As well, tests of result robustness using Heckman's (1979) selection-adjusted estimators employing the full dataset are presented at the conclusion of the empirical analysis. While there are some potential costs to relying on the multiple-offers subsample (selection issues), the benefits are in identifying the affiliation effect, a result that will become clear by comparing the results using the multiple offers methodology (Tables IV through VIII) with "cross-sectional" results based on realized financing outcomes of the entire E-Lab sample (Table IX). In addition, because the multiple-offers subsample likely contains better deals, this bias may actually make it more difficult to find an affiliation effect, since the most promising ventures would potentially have the least to gain from $\mathrm{VC}$ affiliation.

\section{B.2. Variable Definitions and Summary Statistics}


Table II reports variable definitions and summary statistics for the multiple-offers sample in which the unit of analysis is an offer to a start-up, while Table III contains the correlation matrix for these variables.

\section{[Insert TABLE II and TABLE III around here]}

Two measures of price are used in the empirical analysis. Pre-money valuation, the product of the number of shares outstanding before the Series A financing round and the offered per-unit share price $($ mean $=\$ 20.6 \mathrm{M})$, has become a standard measure in the literature (Gompers and Lerner (2000)). Relative valuation offered is the offered pre-money valuation to a start-up relative to the highest offered valuation received by that start-up (mean $=0.83$ ). Note that because many of these financing rounds took place during the late 1990s, the inflated valuations characterizing the "Internet bubble" are likely reflected here. Two additional factors may also be reflected in these valuations: (1) Several of the companies had prior informal funding roundssuch as "angel" and/or "friends and family" rounds before their first professional round, and (2) financing offers given to start-ups with multiple offers averaged $\$ 8.9 \mathrm{M}$ more in pre-money valuation relative to their single-offer counterparts, a statistically significant difference. In any case, instead of focusing on the magnitude of valuation offered, the primary concern here is to explain variance across financing offers for a given start-up. Given these circumstances, relative valuation offered is the preferred measure of price throughout the empirical analysis (though premoney valuation and relative valuation offered are positively correlated at 0.40 ).

The key independent variables are correlates of VC reputation. ${ }^{4}$ In accord with the concept of VC reputation as expected quality based on previous experience, several "objective" measures are employed, based on data as of December 31, 2000 from the Venture Economics database. They include high industry deal experience, a dummy variable equal to 1 if the number of investments the VC has made in the start-up's industrial segment places the VC above the sample median (mean $=0.44$ ). This is the main measure of reputation used in the empirical tables, and is consistent with the concept that VC "domain expertise" is an important input to both VC reputation and VCs' ability to add value to their portfolio companies.

\footnotetext{
${ }^{4}$ If a start-up's Series A round was syndicated, I used information from the lead VC, as prior research suggests that lead investors devote more direct resources to assisting their portfolio companies relative to syndication partners (Gorman and Sahlman (1989)). A syndicated offer is counted as a single offer in this study. Syndicates are common among the accepted offers $(65 \%)$, a fact that is not surprising given the early stage financing rounds examined. Unfortunately, my survey did not capture the full syndicate for offers that were not accepted, and so I am not able to test whether syndication has an effect on the likelihood of offer acceptance and on valuation.
} 
Two measures proxy for services and resources that VCs provide for start-ups. The measure high network resources rating is a dummy equal to 1 if a $\mathrm{VC}$ firm received the maximum Likert-scale measure (of five) in at least one of the following entrepreneur-rated VC network resources: Recruiting resources, contacts with customers and suppliers, and contacts with investment banks (mean $=0.43$ ). A second (alternative) measure of resource transfer is a proxy for the available time a general partner has to potentially devote to start-up development, boards per general partner (mean $=4.2$ ). This measure divides the number of boards of directors on which a VC firm participates by the number of general partners in the VC firm. While the pair-wise correlation between high network resources rating and boards per general partner is not particularly high (0.05), it is interesting to note that there is some degree of correlation between boards per general partner and high industry deal experience (0.46). These correlations may be due to a countervailing boards per general partner effect: A high ratio may proxy for network connections that may be valuable for start-up development.

Finally, two additional measures of reputation are used as robustness checks in the analysis. The measure high normalized funds raised is a dummy equal to 1 if the number of prior funds (excluding buyout funds) the VC has raised per year(s) of operation places the $\mathrm{VC}$ above the sample median. This variable (mean $=0.57$ ) is a measure of $\mathrm{VC}$ success in raising additional financial capital from limited partners, a requirement for survival in the VC industry. ${ }^{5}$ While the internal rate of return (IRR) of past VC funds would be a nice measure of reputation, IRRs are usually held confidential by VC firms (Gompers and Lerner (1999)). Industry reputation rank (mean $=5.9)$ is an ordered ranking, 7 being first best and 1 being worst, of $\mathrm{VC}$ reputation among offers received, as rated by the entrepreneur in the survey instrument (the measure has been reversed from the original survey-based measure for expositional ease). Because this variable is based on entrepreneurial perception and measures relative exclusiveness, industry reputation rank incorporates the notion that the value of affiliation may depend on the VC's hierarchical position (Frank (1985) and Podolny (1993)). The subjective nature of this measure warrants

\footnotetext{
${ }^{5}$ A priori we would expect that high industry deal experience and high normalized funds raised would be positively correlated. The -0.21 pair-wise correlation may result because the two measures are derived indicator variables for the top half of the deal experience and prior funds raised distributions. Reassuringly, the pair-wise correlation between the number of prior VC deals in the industry sector and prior funds raised is positively correlated at 0.56 . As well, the unconditioned pair-wise correlations between high industry deal experience and high normalized funds raised do not reflect control for any other $\mathrm{VC}$ or start-up characteristics.
} 
discussion of its use, however (see below); consequently this measure will be used only for robustness checks in the empirical analysis.

A group of controls for other VC characteristics is used throughout the empirical analysis. The variable corporate $V C$ is a dummy variable (mean $=0.11$ ) for whether the $\mathrm{VC}$ is a corporate investor, since evidence and theory suggest that this method of organizing entrepreneurial finance has different organizational and incentive implications relative to independent venture capitalists (Gompers and Lerner (1999) and Hellmann (2002)). The variable angel investor is a dummy equal to 1 if a financing offer is from an angel or angel group (mean $=$ 0.07). The variable equity taken threshold is a dummy equal to 1 if the investor receives at least $30 \%$ of start-up equity (the median of the sample) (mean $=0.52)$. While equity taken threshold may be endogenous to price, this variable may be an indicator of corporate control implications of an offer, and is therefore included as a control variable. The variable financing offered is the amount of capital offered by the investor in the Series A financing round (mean $=\$ 7.86 \mathrm{M})$. The previous two measures are meant to proxy for the fact that entrepreneurs may prefer offers that allow them to retain a higher stake of equity in their company. As well, larger financing offers may delay the need to return to venture capitalists for additional funding, providing a liquidity benefit to the new venture.

\section{Empirical Results}

The empirical assignment is straightforward - to test the hypotheses that (a) financing offers from more reputable VCs are more likely to be accepted, and (b) more reputable VCs acquire start-up equity at a discount. This section is therefore organized around empirical tables that demonstrate these relationships in both univariate and multivariate settings.

Table IV shows simple univariate comparisons of conditional means without controlling for fixed firm effects. Panel A describes difference in means tests for accepted versus declined financing offers. While the average pre-money value of accepted offers is $\$ 17.7 \mathrm{M}$, the declined offers averaged $\$ 22.1 \mathrm{M}$ (the difference is not statistically significant, however). Accepted offers had higher values of VC reputation relative to non-accepted offers, as measured four ways. The measures normalized industry deal experience (industry deal experience per year(s) of operation), normalized funds raised (number of funds raised per year(s) of operation), industry reputation rank, and high network resources rating all have higher values for accepted offers 
relative to declined ones. The differences in means for the latter three variables are statistically significant. Panel B describes the conditional means of relative valuation offered for the upper and lower halves (divided at the median) of normalized industry deal experience, normalized funds raised, industry reputation rank, and high network resources rating. Examining the conditional means of relative valuation offered rather than pre-money valuation in this context is preferred because the former measure incorporates some information about the comparative nature of the offers. The latter measure does not group offers by start-up firms in any way. While the differences in conditional means for the four reputation measures are not statistically significant, each of the relative means is consistent with the argument that more reputable VCs offer a discount to Series A valuation. Specifically, higher measures of VC reputation are associated with lower valuation offers. These univariate tests, while suggestive, do not control for qualities of the start-up, and so the remaining tables present a more systematic, multivariate analysis.

\section{[Insert TABLE IV around here]}

Table V examines start-up fixed effects logits of VC offer accepted using Chamberlain's (1980) conditional likelihood method. Specification (5-1) shows that in the bivariate case, high industry deal experience is positively associated with VC offer accepted, at a statistically significant level $(5 \%)$ and implies a 2.94 -fold change in the odds of offer acceptance for a discrete change in this measure of $\mathrm{VC}$ reputation. While a more systematic exploration of the robustness of the VC reputation result is found in Table VII, a similar result holds in the bivariate relationship between $V C$ offer accepted and high normalized funds raised. The reputation result is strengthened when a measure of valuation, relative valuation offered, is included in specification (5-2). Notice the relative importance of the reputation effect over the valuation effect on the likelihood that an offer is accepted. Specification (5-3) includes an additional measure of $\mathrm{VC}$ reputation, high network resources rating, and controls for a variety of $\mathrm{VC}$ - and terms-of-financing-effects: Angel investor, corporate venture capital, financing offered, and equity taken threshold. The high network resources rating measure is meant to capture VC value-added effects through contacts and/or resources that could make an offer more attractive (and can contribute to $\mathrm{VC}$ reputation). The estimated coefficient on this variable is positive and statistically significant at the $1 \%$ level. The measure angel investor is meant to capture the fact that a knowledgeable angel investor could be a substitute for a reputable $\mathrm{VC}$ in providing 
certification and business development resources, while the corporate $V C$ method of organizing entrepreneurial finance may have implications for the value they can add to portfolio firms (Gompers and Lerner (1999)). Higher levels of financing offered may be a VC offer feature that may make it more attractive, since entrepreneurs may not have to return as many times or as soon for further financing rounds (fund-raising is an activity that may be quite time-consuming for start-up executives). Finally, the reputation result is not sensitive to the choice of a wide range of equity taken threshold levels between 20 and $50 \%$ of equity taken in the financing round (unreported regressions).

\section{[Insert TABLE V around here]}

Notice that start-up characteristics are not included in these specifications. Since start-up characteristics (such as industry representation) are invariant across offers for a given start-up, including these qualities in the regressions does not affect the results. In addition, because financing offers for a given start-up did not span a large time window, variables on financing timing were not included in the regressions. In the pre-test of the survey, I asked respondents about the time window issue. It was my sense based on these interviews that the time window was not open for a long duration, given the start-up financing conditions of the late 1990s. Unfortunately, in the survey, I only noted the date of the realized Series A funding round, so I am unable to empirically document the time window length. Notwithstanding this shortcoming, the main result from Table $\mathrm{V}$ is that start-ups in this sample may not be selecting investors primarily on the basis of price and valuation; instead, $\mathrm{VC}$ reputation and affiliation effects may indeed be more important.

Table VI presents relative valuation offered start-up fixed effects OLS regressions. The reported standard errors are robust - having been adjusted for clustering by start-up firm. The pairwise specification with high industry deal experience in (6-1) shows a negative relationship that is statistically significant at the $5 \%$ level. As well, the estimated coefficient implies a substantial discount, $14 \%$, on relative valuation offered for a discrete change in the measure of VC reputation.

\section{[Insert TABLE VI around here]}

In (6-2), together with the measure of VC reputation, a dummy variable for VC offer accepted is included as a regressor. Notice that this parameter estimate, while positive (in both 62 ) and (6-3)), does not achieve statistical significance and is small in magnitude. The reputation 
effect persists and is of a slightly larger estimated magnitude relative to the previous specification. In model (6-3), several additional variables (parallel to those used in the prior table) are introduced. While the economic significance of the reputation result is slightly diminished in this specification, the parameter is estimated more precisely, achieving statistical significance at the $1 \%$ level. While the high network resources rating estimate is not statistically significant, it is estimated with a negative coefficient, which is consistent with the main hypothesis tested. The estimated coefficient on equity taken threshold is negative and significant at the $1 \%$ level, suggesting that larger equity stakes are associated with price discounts, though as previously mentioned, endogeneity concerns moderate the interpretation of this control variable. As well, the logarithm of financing offered is estimated with a positive, significant coefficient, indicating that the magnitude of funding, including potential liquidity effects, is associated with higher valuation. While robustness checks of the valuation regressions are presented in Table VIII, the results presented in Table VI are consistent with the idea that startup entrepreneurs pay a premium to accept financing from more reputable venture capitalists.

Because the above-reported results may be an artifact of either the particular measures used or due to selection biases arising from examining the multiple-offers dataset, Tables VII and VIII present robustness checks of the reputation results for the offer acceptance and valuation regressions, respectively. The first three columns of Table VII successively employ alternate measures of $\mathrm{VC}$ reputation in fixed effects logits to study the robustness of the positive correlation between $V C$ offer accepted and reputation in similar specifications to (5-3). Specification (7-1) substitutes high normalized funds raised for high industry deal experience as one of the measures of reputation. While the statistical significance falls to the $10 \%$ level, a discrete change in the funds raised measure corresponds to a doubling of the odds that an offer is accepted. Relative to specification (5-3), the estimated coefficient of high network resource rating is very similar in (7-1), both in magnitude and in statistical significance. In (7-2), industry reputation rank substitutes for high industry deal experience as an alternative measure of VC reputation. In this specification, both industry reputation rank and high network resources rating are positive and significant at the $1 \%$ level, though the estimated coefficient on relative valuation offered is much larger in comparative magnitude than the reputation measures. In (7-3), boards per general partner is used as an alternative measure of $\mathrm{VC}$ resources and is meant to capture the available time that partners in VC firms might have available in mentoring, developing, and 
connecting start-ups. While that variable is estimated with a nearly zero effect, the other reputation measure used in this specification, high industry deal experience, is estimated with quantitatively similar results (statistically and economically) to those found in Table V. Varying the measure of valuation as a control variable from relative valuation offered to the log of premoney valuation causes high industry deal experience to fall to the $6 \%$ level, but does not alter the economic significance of the estimate (unreported specification).

\section{[Insert TABLE VII around here]}

Thus far, the analysis has not taken into account the possibility of a selection bias as a result of only using the multiple offers data, though descriptive data from Table I suggest no statistical differences in the key observable start-up characteristics in the subsamples of the data corresponding to single versus multiple offers. Had we observed the alternate option for entrepreneurs that factually received single offers, would the results persist? Because establishing that counterfactual is difficult, two-stage Heckman (1979) regressions are presented where in the first stage, a probit of the likelihood of multiple offers is estimated using qualities of the start-up. These estimates are used in a second-stage fixed-effects regression of $V C$ offer accepted (in Table VII) and relative valuation offered (in Table VIII) as an adjustment for possible selection effects.

The first-stage regression in Tables VII and VIII includes start-up covariates of the likelihood of receiving multiple offers: The natural logarithm of the pre-Series A number of start-up employees, L initial employees; a dummy equal to 1 if the start-up does not have assigned patents, zero patents; dummy variables for the following industry sectors: Internet industry (including infrastructure, services, and retail subsegments); health science industry (biotechnology and medical devices); computer industry (software and hardware); and year of Series A financing dummies for Year 1998, Year 1999, and Year 2000. ${ }^{6}$ Second-stage fixedeffects Heckman linear probability estimates of $V C$ offer accepted are reported in the final two

\footnotetext{
${ }^{6}$ The omitted category for the industry variables is the communications industry. The results of the selection equation are found at the bottom of Tables VII and VIII. Note that the selection equation includes variables (start-up characteristics) that are likely to act as good instruments because these characteristics are not relevant in the secondstage analysis (they are absorbed by the start-up fixed effects).
} 
columns of Table VII. ${ }^{7}$ While the bivariate specification including high industry deal experience (7-4) is estimated more precisely (significant at the 1\% level) relative to its counterpart in (5-1), the economic magnitude of the estimate is diminished. Meanwhile, the fully specified model (75) yields estimates of similar statistical significance to its counterpart in (5-3), though again with diminished economic significance levels.

Table VIII explores the robustness of the valuation results. A parallel specification structure to that used in the previous robustness table is employed. Specification (8-1) substitutes high normalized funds raised as one of the measures of VC reputation. While the high normalized VC funds raised variable is estimated with a positive (though insignificant) coefficient, recall that univariate comparisons in Table IV indicate that high normalized VC funds raised was negatively correlated with relative valuation offered (although the difference was not statistically significant). In the multivariate regression, the prior funds variable may be picking up some countervailing effects, such that VCs with more prior funds raised are able to raise subsequent funds of larger sizes. ${ }^{8}$ The resulting relaxation in VC liquidity may have a confounding effect on this proxy for VC reputation.

\section{[Insert TABLE VIII around here]}

Specification (8-2) utilizes an alternate measure of VC reputation, industry reputation rank. The variable estimate is negative and statistically significant at the 5\% level. However, an objection to using this measure of reputation is that it is subject to entrepreneurial recall bias and/or ex-post rationalization by the survey respondent. As an imperfect control for these potential effects, a dummy variable for VC offer accepted is included in the specification, because the accepted offer is likely to be the chief candidate for recall and retrospection biases. Although the reputation measure is statistically significant at conventional levels, we should interpret the result cautiously because of the limitations of this measure.

In both specifications (8-1) and (8-2), high network resources rating, a measure of VC services to and resources for the start-up (and an important contributor to VC reputation), is estimated with a negative (though insignificant) coefficient, a finding consistent with the results

\footnotetext{
${ }^{7}$ Testing the robustness of VC offer accepted in the context of fixed effects Heckman selection models presents an econometric challenge — known as the incidental parameters problem (Heckman (1981) and Hsiao (1986)) — in that there are no consistent estimators for fixed-effects probits. Therefore, fixed-effect Heckman regressions using a second-stage linear probability model are reported. The results are robust to this estimation strategy, though the linear probability model is biased when predicted values fall outside of the $(0,1)$ range.

${ }^{8}$ Indeed, the measure does not take into account variation in achieved VC fund size across the sample (e.g., a prior fund of $\$ 750 \mathrm{M}$ is treated the same as a $\$ 30 \mathrm{M}$ fund in the count of prior funds raised).
} 
from Table VI. ${ }^{9}$ Specification (8-3) varies this measure of VC resources to boards per general partner, and while the measure reaches statistical significance at the $10 \%$ level, the economic effect is insignificant. Importantly, note that the high industry deal experience proxy for $\mathrm{VC}$ reputation is robust (though reduced in statistical significance due to some degree of collinearity with boards per general partner). In an unreported regression, the log of pre-money valuation was used as an alternate measure of valuation. The estimates of high industry deal experience were robust to this variation. As well, introducing specifications with dummy variables for the most frequently appearing $\mathrm{VC}$ firms in the sample did not alter the main results (unreported regressions). These indicator variables may be appropriate if we believe that the pricing behavior of a handful of VCs is driving the results (over 100 distinct VC firms are represented in the sample, however).

Finally, in (8-4) and (8-5), fixed-effects Heckman regressions are reported using the entire sample of single and multiple offers in an effort to address potential selection issues. In both the bivariate and the fully specified equations, the results are very similar to those reported in Table VI-while the economic significance of the results is unchanged, the precision of the estimates is slightly enhanced. ${ }^{10}$

A final robustness check suggested that the hypothesized affiliation effects can be found using within-industry variation, though these results are not formally reported because they are merely suggestive. With the caveat that the categories of "Internet" (that includes Internet infrastructure, Internet services, and Internet retailing) and "non-Internet" (that includes biotechnology, medical devices, communications, and computer software and hardware) are very coarse groupings, the measures of $\mathrm{VC}$ reputation (high industry deal experience and high network resources rating) are positively associated with VC offer acceptance and negatively associated with relative valuation offered, although these relationships tend to hold more

\footnotetext{
${ }^{9}$ As well, potential effects of geographic co-location between VC and start-up in facilitating resource exchange were explored. Tests were conducted to examine (a) whether geographic co-location of VC and start-up mattered for offer acceptance or for valuation, and (b) whether VCs located in California or Massachusetts were advantaged in offer acceptance or equity pricing. In both cases, there were no notable results. This may not be the ideal dataset to test such geographic effects, however (most of the start-ups in the dataset are based in Massachusetts).

${ }^{10}$ Estimates of lambda (the inverse of Mill's ratio) and rho (the correlation between error terms in the first and second stage equations) in the Heckman models suggest that selection problems are not severe, and so these selection regressions are not reported for all specifications in the paper.
} 
strongly for the non-Internet subsample and less so for the Internet subsample. ${ }^{11}$ These results are based on parsimonious specifications (keeping the limited sample size issue in mind); however, due to the nature of the dataset, no conclusions about whether these results are due to time period effects can be made.

To conclude the empirical analysis, it is interesting to compare these results to a simple cross-sectional OLS analysis of the natural log of pre-money valuation on all accepted offers, done as if information on the bundle of declined offers were not available. The results, presented in Table IX, are striking.

\section{[Insert TABLE IX around here]}

In (9-1), a bivariate regression, high industry deal experience, is estimated with a positive coefficient, which is significant at the $1 \%$ level. When several start-up qualities are included in specification (9-2), the VC reputation result persists, disappearing in statistical significance only with the inclusion of VC characteristics (9-3), though the reputation measure is still estimated with a positive coefficient in that specification. As previously mentioned, problems of unobserved heterogeneity likely bias these estimates.

\section{Conclusion and Discussion}

I have tested and confirmed the proposition that entrepreneurs are willing to accept a discount on the valuation of their start-up in order to access the capital of venture capitalists with better reputations. These results help deepen our understanding of the market for affiliation by presenting empirical evidence that affiliation is an ordinary economic good for which actors seeking association will face a price-reputation trade off. This finding is consistent with the view that venture capitalists' reputation (which in turn depends on their experience, information network, and direct assistance to the portfolio firms) may be more distinctive than their functionally equivalent financial capital. These conclusions are drawn from an analysis of multiple offers to a set of start-ups, which allows a high degree of statistical control. Because the

\footnotetext{
${ }^{11}$ Because of the contemporaneous emergence of the Internet industry, high industry deal experience may not be a good measure in this empirical setting (I thank the referee for pointing this out). While there is variation in this measure within the subsamples, it is doubtful that high industry deal experience is an adequate proxy for VC knowledge and experience helpful for start-up development in the Internet industries. Using the industry reputation rank proxy for reputation yields strong results, though the problems with this measure are discussed elsewhere in the paper. Using high normalized funds raised yields similar results for the VC offer accepted regressions but rather weak results for the valuation regressions.
} 
characteristics of the start-up can be held constant, only differences in VC reputation across financing offers explain inter-offer variation in offer acceptance and price for start-up equity.

One may wonder why prices charged by competing VCs to acquire the equity in a given start-up can be differentiated in equilibrium, given free entry. VCs with higher reputations may be able to sustain their higher prices (rather than having competition equilibrate prices) as a result of investments in reputation being costly (Shapiro (1983) and Megginson and Weiss (1991)). Consequently, while financial capital per se is not a differentiated good, the reputation of venture capitalists providing the financial capital can be a source of differentiation among VC organizations. The findings in this article are consistent with Kaplan and Schoar's (2003) recent evidence of substantial cross-sectional variation and persistence in VC fund performance.

Several alternate explanations to the empirical pattern have been considered throughout the empirical analysis. First, more savvy VC firms might have foreseen the coming public market downturn and offered lower prices as a result. However, entrepreneurs receiving multiple offers would not necessarily have to accept offers from such VC firms, and so this explanation does not seem consistent with the observed empirical pattern. A second alternative hypothesis is that the term sheet covenants across offers for a given start-up may have differed. Indeed, the price VCs offer for equity may not be the only factor that matters when entrepreneurs select a VC firm, and other dimensions of the term sheet may not be "priced in" to the offered valuations. While surveyed entrepreneurs were asked for a copy of their term sheet offers, very few complied with this request. However, Suchman (1995) provides some evidence of convergence in $\mathrm{VC}$ financing agreements over time as a result of using the same law firms. As well, while Kaplan and Strömberg (2003) find that covenants in VC contracts differ by stage of start-up development, the offered terms of financing for a given start-up across VC firms may not be as variable. Nevertheless, different VCs probably prefer different terms, and offered terms are likely to vary even for a given start-up in a particular time period. As a result, comparing offers primarily on the basis of price is an inherent limitation of the present study.

Several additional issues associated with the data used for this study result in interpretational concerns. First, are the findings simply an artifact of the sample used? Although this group of companies might be of higher quality relative to average start-ups (assuming that the decision to be involved with MIT is a signal of quality), the sample, while modest at 148 offers, may represent a conservative test of the hypothesized effect. High quality entrepreneurs 
have their own reputations and established networks, which would tend to obviate the need to pay a premium to access capital from more experienced funding sources. In any case, employing start-up fixed effects makes this quality issue less important for the purposes of the empirical analysis. Indeed, the unique timing of the study in an environment in which many VCs were "chasing after deals" allowed identification of the market for affiliation-though it does not necessarily address the applicability of these results to other time periods or other relationships. It is difficult, unfortunately, to speculate on that answer.

A second issue is whether the results are produced from the competitive effect associated with studying a sample of multiple offers. This proposition is also hard to evaluate, however, due to the difficulty of establishing a counterfactual to single-offer situations. On a related note, a deeper understanding of the process leading to multiple offers would be desirable. The manifold processes generating offers (some of which are unobserved, such as entrepreneurial charisma), as well as the disparate bargaining processes leading to offers, makes the fixed-effects methodology attractive in controlling for unobserved heterogeneity. Nevertheless, had I collected information about the sequencing of offers, I might have been able to gain some empirical insight into the process generating multiple offers. Sequencing data may have also helped in beginning to empirically disentangle the pure affiliation effect from the VC value-added effect.

Two issues related to offers and how they might affect the interpretation of the results are also worth discussing. First, what if entrepreneurs "shopped" their deal to other VCs without receiving a formal term sheet? Unfortunately, I do not have the history of how many pitches entrepreneurs made to different $\mathrm{VC}$ groups without receiving formal offers. The results may be biased if (a) informal offers were leveraged to negotiate more favorable formal offers, and (b) VCs with a less established reputation were more willing to revise their valuations upward relative to $\mathrm{VCs}$ with more established reputations. Unfortunately, data constraints prohibit this analysis; however, survey respondents were instructed to provide information on final formal term sheets only (including informal offers would have subjected the sample to entrepreneurial interpretation of what constituted an informal offer). A second issue is whether some of the high valuation offers were withdrawn by VCs as the negotiations became more serious. Again, systematic data are unfortunately unavailable to address this question. If withdrawals came from across the full distribution of VCs, this would not bias the results. If, on the other hand, withdrawals were systematically from less-reputable VCs, the study would be biased toward 
finding the results (and the opposite would be true if reputable VCs tended to withdraw offers). Given the market environment ("money chasing deals") in which these data were collected in the second half of 2000 and my conversations with survey respondents, however, I believe that offer withdrawal was not a pervasive phenomenon in this sample. However, because I cannot rule out these two issues, they represent caveats to the study.

A final issue is interpreting what start-ups are buying. For example, industry deal experience in the start-up's sector can proxy for both the scope of the VC's information network as well as the VC's ability to evaluate deals. Unfortunately, the data in this study do not provide a clean way of disentangling these effects. As well, higher ability entrepreneurs may be taking a lower offer in an effort to signal quality (Spence (1974)). While the empirical setting and the documented empirical patterns make this explanation unlikely, the proposition cannot be ruled out.

Looking to the future, while this study does not test the ex-post performance implications of selecting a particular VC, it would be interesting to do so. For example, did start-ups accepting funding from more reputable VCs receive higher step-ups in valuation in subsequent rounds? Did they achieve an IPO faster or deliver products to the market more quickly? ${ }^{12}$ Nevertheless, the findings in this study are consistent with the theory that entrepreneurs who are tied into more connected networks at reputable VC firms expect to come across more opportunities for start-up growth, but must pay a premium for such access.

\footnotetext{
${ }^{12}$ As a preliminary analysis, I examined as of January 31, 2002 whether accepting funding from a more reputable VC was correlated with surviving in the post-bubble shakeout period. While there are issues about the appropriate lag time to examine such an effect, a substantial fraction of the firms in the sample are either still operating, or were acquired for an undisclosed amount, rendering an assessment of "success" difficult. For these reasons, these preliminary analyses were not illuminating.
} 


\section{APPENDIX: \\ MIT Sloan Financing New \\ High-Tech Ventures Survey}

Name of Firm:

Location (city, state):

Part I: Background Information

\section{A. Founding the Company}

When was your company founded (month, year)?

When was your company incorporated (month, year)?

\begin{tabular}{|l|l|l|l|l|l|}
\hline Name of Founder & $\begin{array}{l}\text { Current job } \\
\text { title }\end{array}$ & Company & $\begin{array}{l}\text { Reason for leaving } \\
\text { (if applicable) }\end{array}$ & $\begin{array}{l}\text { \# of prior } \\
\text { start-ups } \\
\text { founded }\end{array}$ & $\begin{array}{l}\text { Name of prior } \\
\text { start-ups }\end{array}$ \\
\hline & & & & & \\
\hline & & & & & \\
\hline & & & & & \\
\hline & & & & & \\
\hline
\end{tabular}

If the founding team previously started other companies, which category best describes the average approximate internal rate of return(s) on Series A investment for those previous venture(s)?
$\square<0$
$\square-10 \%$
$\square 11-50 \%$
$51-100 \%$
$\square 101-500 \% \quad \square>500 \%$

How many of those founded firm(s) were taken public?

At the time of start-up, what did your founding team consider to be the company's key competitive advantage? (select the most important two)

$\square$ Establishing a new market $\square$ Establishing a new technology $\square$ Recruiting superior personnel

$\square$ Establishing an advantageous cost position $\square$ Superior positioning in the product niche

$\square$ Maintaining superior intellectual property

Superior customer service $\&$ responsiveness

Superior product quality / reliability

Other: 


\section{B. Employee Information}

Number of Employees: at the time of raising Series A financing:

as of $7 / 1 / 00$ :

Current number of employees in each of the following functions:

$\begin{array}{llll}\text { R\&D } \quad \text { Sales } \quad \text { Marketing } & \begin{array}{l}\text { Manufacturing General \& } \\ \text { or Operations Admin. }\end{array} & \text { Service } \\ & \end{array}$

Please indicate which of the senior executive officers below was on the founding team. If not on the founding team, please designate from what source the executive officer came. Please " $x$ " out the position if it does not exist in your company, and draw lines connecting positions, if one person holds multiple positions.

On founding team

Or, contact through:

Personal friend

Classmate

Co-worker

Investor/financier

Recruiter

Advisor

\section{CEO COO CFO}

CFO CTO

CTO VP, Marketing

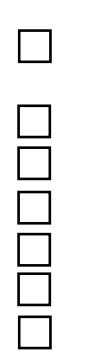

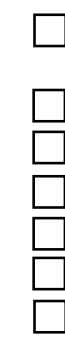

VP, VP, Other:

Sales Bus. Dev.

\section{Financing the Company}

Did you have a completed business plan before getting your Series A funding? $\square$ Yes $\square$ No

Time from completing the business plan to receiving your first financing offer: months

Who were the participants in your company's financing(s) to date? If a number of "angel investors" participated, please group them all as "Angels" in the Investor column. If applicable, please place an asterisk (*) next to the lead investor.

$\underline{\text { Round }} \quad \underline{\text { Date }} \quad \underline{\text { Investor }} \quad \underline{\text { Amount }}$

Total number of financing offers for the Series A round: 
What is the current percentage of corporate ownership held by the following groups:

\begin{tabular}{|c|c|c|c|c|c|}
\hline Founders & $\begin{array}{l}\text { Employees } \\
\text { \& option pool }\end{array}$ & $\begin{array}{l}\text { Venture } \\
\text { canitalists }\end{array}$ & $\begin{array}{l}\text { "Angel" } \\
\text { investors }\end{array}$ & $\begin{array}{l}\text { Strategic } \\
\text { investors }\end{array}$ & Public \\
\hline$\%$ & $\%$ & $\%$ & $\%$ & $\%$ & \\
\hline
\end{tabular}

For the Series A financing, which of the following areas were the subject of active negotiation between the parties?

Pre-money valuation

Board representation

Employee option pool

Vesting schedules

Liquidation rights

Anti-dilution clauses

Other (specify:

Not active $\quad$ Very active

$\begin{array}{llllll}\text { N/A } & 1 & 2 & 3 & 4 & 5 \\ \text { N/A } & 1 & 2 & 3 & 4 & 5 \\ \text { N/A } & 1 & 2 & 3 & 4 & 5 \\ \text { N/A } & 1 & 2 & 3 & 4 & 5 \\ \text { N/A } & 1 & 2 & 3 & 4 & 5 \\ \text { N/A } & 1 & 2 & 3 & 4 & 5 \\ \text { N/A } & 1 & 2 & 3 & 4 & 5\end{array}$

Why did you select the offer you chose?

\section{Building Corporate Governance}

Number of members of the Board of Directors:

How many directors are from: within the firm

outside the firm

Number of board members appointed by your investors:

Please rate the importance of the following functions of your investor-appointed directors:

Oversight and monitoring of the company

Source of advice and counsel to the company

Source of external business contacts

Recruiting and team building

Market validation/prestige

\section{LOW}

$\mathrm{HIGH}$

Do you have a board of advisors? $\square$ Yes $\square$ No

Please rate the importance of the following functions of your board of advisors, if you have one:

Oversight and monitoring of the company

Source of advice and counsel to the company

Source of external business contacts

Recruiting and team building

Market validation/prestige

\begin{tabular}{|c|c|c|c|c|c|}
\hline \multicolumn{3}{|c|}{ LOW } & & & HIGH \\
\hline N/A & 1 & 2 & 3 & 4 & 5 \\
\hline N/A & 1 & 2 & 3 & 4 & 5 \\
\hline $\mathrm{N} / \mathrm{A}$ & 1 & 2 & 3 & 4 & 5 \\
\hline $\mathrm{N} / \mathrm{A}$ & 1 & 2 & 3 & 4 & 5 \\
\hline N/A & 1 & 2 & 3 & 4 & 5 \\
\hline
\end{tabular}




\section{E. Product, Technology, and Strategy}

Which industrial classification best describes your company:

$\begin{array}{llll}\square \text { Internet: Services } & \square \text { Internet: E-tailer } & \square \text { Internet: Infra. } & \square \text { Internet: Other } \\ \square \text { Software } & \square \text { Medical Devices } & \square \text { Biotech } & \square \text { Communications } \\ \square \text { Computer hardware } & \square \text { Other (specify: } & \text { ) }\end{array}$

\begin{tabular}{lllll} 
Year 1 & 2 & 3 & 4 & 5 \\
\hline
\end{tabular}

Actual company revenues:

(Thousands of dollars)

\begin{tabular}{lllll} 
Year 1 & 2 & 3 & 4 & 5 \\
\hline
\end{tabular}

Actual corporate profits/losses:

Number of: patent applications filed by your firm: patents issued to your company:

patents pending:

Has your firm entered into any technology licensing deals?

$\square$ Yes: licensed out $\square$ Yes: licensed in

If your firm has licensed-out, what were the terms? $\quad \square$ Exclusive $\square$ Non-exclusive

Who were the licensees? $\square$ Product market incumbents $\square$ Product market entrants

\begin{tabular}{lllll} 
Year 1 & 2 & 3 & 4 & 5 \\
\hline
\end{tabular}

Actual licensing revenues by yr:

(Thousands of dollars)

Has your firm been acquired since its inception?

If so, by whom?

Yes

No

At the time of your Series A financing, please rate the importance of each of the following as obstacles to the commercial success of your enterprise:

Lack of brand name image

Lack of distribution channels/sales force

Lack of servicing resources

Lack of manufacturing capability
Not an obstacle

$\begin{array}{llllll}\text { N/A } & 1 & 2 & 3 & 4 & 5 \\ \text { N/A } & 1 & 2 & 3 & 4 & 5 \\ \text { N/A } & 1 & 2 & 3 & 4 & 5 \\ \text { N/A } & 1 & 2 & 3 & 4 & 5\end{array}$




\section{Part II: Financing Offer Characteristics}

Please complete one record for each term sheet you received, copying this form as many times as needed. If possible, please also attach a copy of the term sheet received from each investor organization.

Name of Investor:

Location (City/State):

How did you make initial contact with this investor?

Sent an unsolicited business plan

$\square \mathrm{He} / \mathrm{she}$ was a personal contact

Referred by an advisor or friend

Other (specify: )

If you were referred to the investor through a friend or knew the investor directly, how did you come to know that person?

Does this investor host a regular conference or formal networking event for top managers of its portfolio companies?

$\square$ Yes $\quad \square$ No

Does this investor have dedicated personnel to help its portfolio companies in the following areas:
Recruiting
$\square$ Yes
$\square$ Yes
Finance \& accounting
Business development
$\square$ No
$\square$ No
$\square$ Yes
No

Please rate this financing offer/investor along the following dimensions:

Overall reputation of this investor

Reputation in your industrial sector

$\begin{array}{llllll}\text { LOW } & & & & \text { HIGH } \\ \text { N/A } & 1 & 2 & 3 & 4 & 5 \\ \text { N/A } & 1 & 2 & 3 & 4 & 5 \\ \text { N/A } & 1 & 2 & 3 & 4 & 5 \\ \text { N/A } & 1 & 2 & 3 & 4 & 5 \\ \text { N/A } & 1 & 2 & 3 & 4 & 5 \\ \text { N/A } & 1 & 2 & 3 & 4 & 5 \\ \text { N/A } & 1 & 2 & 3 & 4 & 5\end{array}$

Expected availability to mentor the team

"Chemistry" with this investor

Expected ability to recruit key managers

Potential contacts with key customers or suppliers

Potential contacts with investment banks

What pre-money valuation did this investor assign to your company at the Series A round?

$\$$ Million

What post-money valuation did this investor assign to your company at the Series A round?

$\$$ Million

Proposed equity stake taken by this investor as a result of this financing offer: 


\section{Part III: Financing Offer Comparison Table}

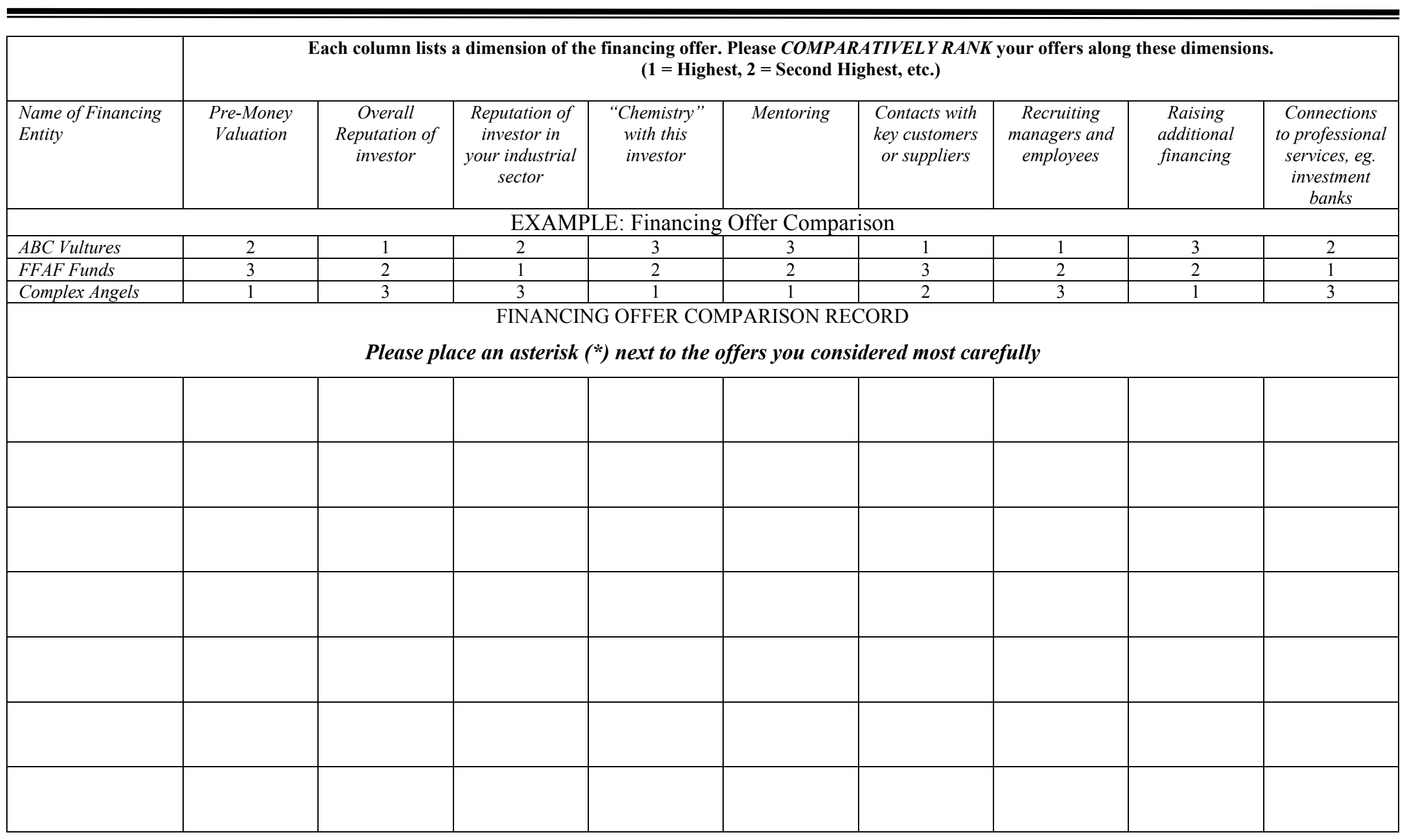




\section{REFERENCES}

Admati, Anat R., and Paul C. Pfleiderer, 1994, Robust financial contracting and the role of venture capitalists, Journal of Finance 49, 371-402.

Aoki, Masahiko, 2000, Information and governance in the Silicon Valley model, in Xavier Vives, ed.: Corporate Governance: Theoretical and Empirical Perspectives (Cambridge University Press, Cambridge, UK).

Bagwell, Laurie S., and B. Douglas Bernheim, 1996, Veblen effects in a theory of conspicuous consumption, American Economic Review 86, 349-373.

Barry, Christopher B., Chris J. Muscarella, John W. Peavy III, and Michael R. Vetsuypens, 1990, The role of venture capital in the creation of public companies: Evidence from the goingpublic process, Journal of Financial Economics 27, 447-471.

Beatty, Randolph P., and Jay R. Ritter, 1986, Investment banking, reputation and the underpricing of initial public offerings, Journal of Financial Economics 15, 213-232.

Biglaiser, Gary, 1993, Middlemen as experts, RAND Journal of Economics 24, 212-223.

Booth, James R., and Richard L. Smith, II, 1986, Capital raising, underwriting and the certification hypothesis, Journal of Financial Economics 15, 261-281.

Boston Globe, 2000, The matrix, June 6, D1.

Bygrave, William D., and Jeffrey A. Timmons, 1992, Venture Capital at the Crossroads (Harvard Business School Press, Boston, MA).

Chamberlain, Gary, 1980, Analysis of covariance with qualitative data, Review of Economics Studies 47, 225-238.

Frank, Robert H., 1985, The demand for unobservable and other nonpositional goods, American Economic Review 75, 101-116.

Gans, Joshua S., David H. Hsu and Scott Stern, 2002, When does start-up innovation spur the gale of creative destruction? RAND Journal of Economics 33, 571-586.

Gompers, Paul, 1996, Grandstanding in the venture capital industry, Journal of Financial Economics 42, 133-156.

Gompers, Paul, and Josh Lerner, 1999, The Venture Capital Cycle (MIT Press, Cambridge, MA).

Gompers, Paul, and Josh Lerner, 2000, Money chasing deals? The impact of fund inflows on private equity valuations, Journal of Financial Economics 55, 281-325. 
Gorman, Michael, and William A. Sahlman, 1989, What do venture capitalists do? Journal of Business Venturing 4, 231-248.

Heckman, James J., 1979, Sample selection bias as a specification error, Econometrica 47, 153161.

Heckman, James J., 1981, The incidental parameters problem and the problem of initial conditions in estimating a discrete time-discrete data stochastic process, in Charles F. Manski and Daniel L. McFadden, eds.: Structural Analysis of Discrete Data with Econometric Applications (MIT Press, Cambridge, MA).

Hellmann, Thomas, 1998, The allocation of control rights in venture capital contracts, RAND Journal of Economics 29, 57-76.

Hellmann, Thomas, 2002, A theory of strategic venture investing, Journal of Financial Economics 64, 285-314.

Hellmann, Thomas, and Manju Puri, 2000, The interaction between product market and financing strategy: The role of venture capital, Review of Financial Studies 13, 959-984.

Hellmann, Thomas, and Manju Puri, 2002, Venture capital and the professionalization of start-up firms: Empirical evidence, Journal of Finance 57, 169-197.

Hsiao, Cheng, 1986, Analysis of Panel Data (Cambridge University Press, Cambridge, UK).

Kaplan, Steven, and Antoinette Schoar, 2003, Private equity performance: Returns, persistance and capital, Working paper, University of Chicago Graduate School of Business.

Kaplan, Steven, and Per Strömberg, 2001, Venture capitalists as principals: Contracting, screening, and monitoring, American Economic Review 91, 426-430.

Kaplan, Steven, and Per Strömberg, 2002, Characteristics, contracts, and actions: Evidence from venture capitalist analyses, Working paper, University of Chicago Graduate School of Business.

Kaplan, Steven, and Per Strömberg, 2003, Financial contracting theory meets the real world: An empirical analysis of venture capital contracts, Review of Economic Studies 70, 281-315.

Lerner, Josh, 1995, Venture capitalists and the oversight of private firms, Journal of Finance 50, 301-318.

Lindsey, Laura, 2002, The venture capital keiretsu effect: An empirical analysis of strategic alliances among portfolio firms, Working paper, Stanford University. 
MacMillan, Ian C., David M. Kulow, and Roubina Khoylian, 1989, Venture capitalists' involvement in their investments: Extent and performance, Journal of Business Venturing 4, 27-47.

Megginson, William, and Kathleen Weiss, 1991, Venture capital certification in initial public offerings, Journal of Finance 46, 879-903.

National Venture Capital Association Yearbook, 2001 (Thomson Financial/Venture Economics, Arlington, Virginia).

New York Times, 2000, Venture capitalists, venturing beyond capital, October 15, C1.

Podolny, Joel, 1993, A status-based model of market competition, American Journal of Sociology 98, 829-872.

Roberts, Edward B., 1991, Entrepreneurs in High Technology: Lessons from MIT and Beyond (Oxford University Press, Oxford, UK).

Sahlman, William A., 1997, How to write a great business plan, Harvard Business Review 75, 98-108.

Shapiro, Carl, 1983, Premiums for high quality products as returns to reputation, Quarterly Journal of Economics 98, 659-680.

Smith, D. Gordon, 1999, How early stage entrepreneurs evaluate venture capitalists, in Frontiers of Entrepreneurship Research (Babson College, Boston, MA).

Sorenson, Olav, and Toby E. Stuart, 2001, Syndication networks and the spatial distribution of venture capital investments, American Journal of Sociology 106, 1546-1586.

Spence, A. Michael, 1974, Market Signaling: Informational Transfer in Hiring and Related Screening Processes (Harvard University Press, Cambridge, MA).

Stern, Scott, 2000, Do scientists pay to be scientists? NBER Working paper \#7410.

Stuart, Toby E., Ha Hoang, and Ralph Hybels, 1999, Interorganizational endorsements and the performance of entrepreneurial ventures, Administrative Science Quarterly 44, 315-349.

Suchman, Mark C., 1995, Localism and globalism in institutional analysis: The emergence of contractual norms in venture finance, in W. Richard Scott and Søren Christensen, eds.: The Institutional Construction of Organizations (Sage Publications: Thousand Oaks, CA). 


\section{Table I \\ Description of the Overall Dataset}

This table describes the overall sample of Series A round financing offers to start-ups. Panel A describes the distribution of start-ups by year of incorporation. Panel B describes the overall sample, together with the distribution of offers and characteristics of the start-ups. For the sample of single and multiple offers, $80.5 \%$ of the 149 firms accepted their best (and sometimes only) financing offer. Of the 51 firms receiving multiple offers, $57 \%$ did not accept their best financial offer, leaving \$173.9M "on the table," the sum of the differences between the best financial offer and the accepted offer. For the group of firms receiving multiple offers and declining their best financial offer, this amount represents an average of $33.2 \%$ pre-money valuation discount as a fraction of their accepted offers. For the overall sample of single and multiple offers, this statistic is $12.5 \%$. The measure internet industry includes services, infrastructure, retail, or other; computer industry includes software and hardware; health industry includes medical devices and biotechnology. The measure high industry deal experience is a dummy variable equal to 1 if the number of deals the $\mathrm{VC}$ has previously funded in the target start-up's industrial segment places the $\mathrm{VC}$ above the sample median. The measure high normalized funds raised is a dummy variable equal to 1 if the number of prior funds (excluding buyout funds) the $\mathrm{VC}$ has raised per years of operation places the $\mathrm{VC}$ above the sample median. The measure high network resources rating is a dummy equal to 1 if a $\mathrm{VC}$ firm received the maximum Likert-scale measure (of 5) in at least one of the following entrepreneur-rated VC network resources: Recruiting resources, contacts with customers and suppliers, or contacts with investment bankers. The measure corporate $V C$ is a dummy equal to 1 if the $\mathrm{VC}$ is a corporate $\mathrm{VC}$. The measure angel investor is a dummy variable equal to 1 if a financing offer is from an angel investor or angel group. The measure financing offered is the amount of capital offered (in $\$ \mathrm{M})$ by the investor. The measure equity taken threshold is a dummy variable equal to 1 if the investor receives at least $30 \%$ of start-up equity (the median of the sample) as a result of the Series A financing offer. Panels C and D report the conditional means of start-up and VC characteristics, respectively, for the single offer and multiple offer subsamples of the dataset. The $t$-tests of equal means between these sub-samples are also reported.

Panel A. Distribution of number of start-ups by year of incorporation

\begin{tabular}{ccccccccccccc}
\hline & 1984 & 1989 & 1990 & 1992 & 1993 & 1994 & 1995 & 1996 & 1997 & 1998 & 1999 & 2000 \\
\hline & 1 & 1 & 1 & 2 & 5 & 5 & 13 & 14 & 19 & 27 & 39 & 22 \\
\hline
\end{tabular}

Panel B. Description of start-ups and VCs by number of offers received

\begin{tabular}{lcccccccc}
\hline & \multicolumn{10}{c}{ Number of offers received } \\
\cline { 2 - 9 } Start-up characteristics & \multicolumn{1}{c}{2} & \multicolumn{1}{c}{3} & 4 & 5 & 6 & 7 & Sum/Avg. \\
\hline Number of start-up firms & 98 & 21 & 20 & 6 & 3 & 0 & 1 & 149 \\
\# firms accepting best financial offer & 98 & 9 & 11 & 1 & 1 & NA & 0 & 120 \\
\# firms declining best financial offer & 0 & 12 & 9 & 5 & 2 & NA & 1 & 29 \\
\% firms accepting best financial offer & 100 & 42.9 & 55 & 16.7 & 33.3 & NA & 0 & $80.5 \%$ \\
\$M “left on table" & 0 & 56.5 & 50.8 & 42.5 & 8.8 & NA & 15.3 & $\$ 174 \mathrm{M}$ \\
Accepted pre-money value & 869.4 & 147.3 & 74.2 & 256.5 & 11.3 & NA & 34.7 & $1393 \mathrm{M}$ \\
Foregone value as a \% of accepted & 0 & 38.4 & 68.5 & 16.6 & 77.9 & NA & 44.1 & $12.5 \%$ \\
$\quad$ pre-money value & & & & & & & & \\
Year start-up founded & 1997.2 & 1998.1 & 1997.6 & 1997.2 & 1998.3 & NA & 1995.0 & 1997.4 \\
Year of Series A funding & 1998.5 & 1998.8 & 1998.8 & 1999.0 & 1999.3 & NA & 1999.0 & 1998.6 \\
Pre-money valuation (\$M) & 8.9 & 11.3 & 15.4 & 48.6 & 10.9 & NA & 34.7 & 11.9 \\
Pre-Series A employment & 9.3 & 9.4 & 9.7 & 23.0 & 15.7 & NA & 15.0 & 10.1 \\
First year revenues (\$M) & 0.2 & 0.3 & 0.3 & 0.8 & 0.1 & NA & 0.0 & 0.3 \\
\# patent app. 12/31/2000 & 4.9 & 3.8 & 7.8 & 12.2 & 3.0 & NA & 2.0 & 5.4 \\
\# patent grants as of 12/31/2000 & 1.2 & 0.5 & 2.0 & 0.7 & 1.0 & NA & 2.0 & 1.2 \\
Internet industry & 0.5 & 0.5 & 0.6 & 0.8 & 1.0 & NA & 1.0 & 0.5 \\
Computer industry & 0.2 & 0.3 & 0.2 & 0.2 & 0.0 & NA & 0.0 & 0.2 \\
Health industry & 0.1 & 0.1 & 0.2 & 0.0 & 0.0 & NA & 0.0 & 0.1 \\
Communications industry & 0.1 & 0.1 & 0.2 & 0.0 & 0.0 & NA & 0.0 & 0.1 \\
Massachusetts-based start-up & 0.7 & 0.8 & 0.8 & 0.8 & 0.7 & NA & 1.0 & 0.7 \\
California-based start-up & 0.1 & 0.1 & 0.2 & 0.0 & 0.3 & NA & 0.0 & 0.1
\end{tabular}


Table I - continued

\begin{tabular}{|c|c|c|c|c|c|c|c|c|}
\hline \multirow[b]{2}{*}{ VC Characteristics } & \multicolumn{8}{|c|}{ Number of offers received } \\
\hline & 1 & 2 & 3 & 4 & 5 & 6 & 7 & Sum/Avg. \\
\hline High industry deal experience & 0.2 & 0.5 & 0.5 & 0.5 & 0.7 & NA & 1.0 & 0.3 \\
\hline High normalized funds raised & 0.6 & 0.7 & 0.7 & 0.5 & 1.0 & NA & 1.0 & 0.7 \\
\hline High network resources rating & 0.4 & 0.5 & 0.5 & 0.7 & 0.7 & NA & 1.0 & 0.4 \\
\hline Corporate VC & 0.1 & 0.0 & 0.1 & 0.0 & 0.0 & NA & 0.0 & 0.0 \\
\hline Angel investor & 0.2 & 0.1 & 0.2 & 0.0 & 0.0 & NA & 0.0 & 0.2 \\
\hline Financing offered (\$M) & 4.3 & 6.3 & 6.0 & 14.3 & 6.0 & NA & 13.7 & 5.3 \\
\hline Equity taken threshold & 0.5 & 0.7 & 0.5 & 0.7 & 0.7 & NA & 0.0 & 0.6 \\
\hline
\end{tabular}

Panel C. Comparison of start-up characteristics across offers received subsamples

\begin{tabular}{lccc}
\hline Variable & $\begin{array}{c}\text { Single offer } \\
\text { mean }\end{array}$ & $\begin{array}{c}\text { Multiple offer } \\
\text { mean }\end{array}$ & $t$-stat for equal means \\
\hline Year start-up founded & 1997.19 & 1997.77 & -1.36 \\
Year of Series A financing & 1998.53 & 1998.86 & -1.18 \\
Pre-Series A employment & 9.32 & 11.59 & -1.31 \\
First year revenues (\$M) & 0.23 & 0.35 & -0.86 \\
\# Patent applications as of 12/31/2000 & 4.94 & 6.28 & -0.62 \\
\# Patent grants as of 12/31/2000 & 1.21 & 1.14 & 0.11 \\
Internet industry & 0.48 & 0.59 & -1.26 \\
Computer industry & 0.24 & 0.20 & 0.54 \\
Health industry & 0.09 & 0.10 & -0.12 \\
Communications industry & 0.11 & 0.10 & 0.26 \\
Massachusetts-based start-up & 0.72 & 0.78 & -0.79 \\
California-based start-up & 0.13 & 0.12 & 0.26 \\
\hline
\end{tabular}

Panel D. Comparison of VC characteristics across offers received subsamples

\begin{tabular}{lccc}
\hline Variable & $\begin{array}{c}\text { Single offer } \\
\text { mean }\end{array}$ & $\begin{array}{c}\text { Multiple offer } \\
\text { mean }\end{array}$ & $\begin{array}{c}t \text {-stat for equal } \\
\text { means }\end{array}$ \\
\hline Pre-money valuation $(\$ M)$ & 8.87 & 17.73 & $-2.75^{* * *}$ \\
High industry deal experience & 0.25 & 0.51 & $-3.35^{* * *}$ \\
High normalized funds & 0.64 & 0.67 & -0.29 \\
High network resources rating & 0.39 & 0.55 & $-1.89^{*}$ \\
Corporate VC & 0.05 & 0.02 & $-2.93^{* * *}$ \\
Angel investor & 0.22 & 0.08 & $2.25^{* *}$ \\
Financing offered $(\$ M)$ & 4.33 & 7.27 & $-2.43^{* *}$ \\
Equity taken threshold & 0.53 & 0.61 & -0.90 \\
\hline
\end{tabular}




\section{Table II \\ Descriptive Statistics of the Multiple Offers Sample}

This table provides descriptive statistics of variables used in Tables III through VIII. The measure VC offer accepted is a dummy equal to 1 if an offer was accepted by the entrepreneur. The measure pre-money valuation is the product of the number of outstanding shares before the Series A round and the share price before the financing round (in $\$ \mathrm{M})$. The measure relative valuation offered is the offered pre-money valuation to a start-up relative to the highest offered valuation received by that start-up. The measure high industry deal experience is a dummy variable equal to 1 if the number of deals the $\mathrm{VC}$ has previously funded in the target start-up's industrial segment places the VC above the sample median. The measure industry reputation rank is the rank (a ranking of 7 being first best, with lower values indicating lower reputation) of $\mathrm{VC}$ reputation among offers received, as rated by the entrepreneur. The measure high normalized funds raised is a dummy variable equal to 1 if the number of prior funds (excluding buyout funds) the $\mathrm{VC}$ has raised per years of operation places the $\mathrm{VC}$ above the sample median. The measure high network resources rating is a dummy equal to 1 if a $\mathrm{VC}$ firm received the maximum Likert-scale measure (of 5) in at least one of the following entrepreneur-rated VC network resources: Recruiting resources, contacts with customers and suppliers, or contacts with investment bankers. The measure boards per general partner is the number of boards of directors per general venture capital partner. The measure corporate $V C$ is a dummy equal to 1 if the $\mathrm{VC}$ is a corporate VC. The measure angel investor is a dummy variable equal to 1 if a financing offer is from an angel investor or angel group. The measure financing offered is the amount of capital offered (in \$M) by the investor. The measure equity taken threshold is a dummy variable equal to 1 if the investor receives at least $30 \%$ of start-up equity (the median of the sample) as a result of the Series A financing offer.

\begin{tabular}{lrrc}
\hline \multicolumn{1}{c}{ Variable } & Mean & Std. Dev. & Source \\
\hline Dependent variables & & & \\
VC offer accepted & 0.345 & 0.477 & MIT Survey \\
Pre-money valuation & 20.589 & 32.935 & MIT Survey \\
Relative valuation offered & 0.826 & 0.215 & MIT Survey \\
VC reputation measures & & & \\
High industry deal experience & 0.439 & 0.498 & Venture Economics \\
Industry reputation rank & 5.905 & 1.163 & MIT Survey \\
High normalized funds raised & 0.568 & 0.497 & Venture Economics \\
High network resources rating & 0.432 & 0.497 & MIT Survey \\
Boards per general partner & 4.198 & 2.405 & Venture Economics \\
VC- and financing term controls & & & \\
Corporate VC & 0.048 & 0.214 & Corporate web sites \\
Angel investor & 0.068 & 0.253 & MIT Survey \\
Financing offered & 7.863 & 8.944 & MIT Survey \\
Equity taken threshold & 0.520 & 0.501 & MIT Survey \\
\hline
\end{tabular}




\section{Table III}

\section{Pair-wise Correlation Matrix}

This table provides a pair-wise correlation matrix of the variables used in the empirical analysis. Statistically significant relationships at the $5 \%$ level are denoted with an asterisk (*). The measure VC offer accepted is a dummy equal to 1 if an offer was accepted by the entrepreneur. The measure pre-money valuation is the product of the number of outstanding shares before the Series A round and the share price before the financing round (in \$M). The measure relative valuation offered is the offered pre-money valuation to a start-up relative to the highest offered valuation received by that start-up. The measure high industry deal experience is a dummy variable equal to 1 if the number of deals the VC has previously funded in the target start-up's industrial segment places the VC above the sample median. The measure industry reputation rank is the rank (a ranking of 7 being first best, with lower values indicating lower reputation) of VC reputation among offers received, as rated by the entrepreneur. The measure high normalized funds raised is a dummy variable equal to 1 if the number of prior funds (excluding buyout funds) the $\mathrm{VC}$ has raised per years of operation places the VC above the sample median. The measure high network resources rating is a dummy equal to 1 if a VC firm received the maximum Likert-scale measure (of 5) in at least one of the following entrepreneur-rated VC network resources: Recruiting resources, contacts with customers and suppliers, or contacts with investment bankers. The measure boards per general partner is the number of boards of directors per general venture capital partner. The measure corporate VC is a dummy equal to 1 if the VC is a corporate VC. The measure angel investor is a dummy variable equal to 1 if a financing offer is from an angel investor or angel group. The measure financing offered is the level of capital offered (in $\$ \mathrm{M}$ ) by the investor. The measure equity taken threshold is a dummy variable equal to 1 if the investor receives at least $30 \%$ of start-up equity (the median of the sample) as a result of the Series A financing offer.

\begin{tabular}{|c|c|c|c|c|c|c|c|c|c|c|c|c|}
\hline & $(1)$ & $(2)$ & (3) & $(4)$ & $(5)$ & $(6)$ & (7) & $(8)$ & (9) & $(10)$ & $(11)$ & $(12)$ \\
\hline (1) VC offer accepted & 1 & & & & & & & & & & & \\
\hline (2) Pre-money valuation & -0.05 & 1 & & & & & & & & & & \\
\hline (3) Relative valuation offered & 0.05 & $0.40^{*}$ & 1 & & & & & & & & & \\
\hline (4) High industry deal exp. & 0.13 & $0.26^{*}$ & 0.03 & 1 & & & & & & & & \\
\hline (5) Industry rep. rank & $0.43 *$ & $-0.22 *$ & -0.04 & 0.12 & 1 & & & & & & & \\
\hline (6) High norm. funds raised & 0.15 & $-0.25 *$ & -0.03 & $-0.21 *$ & 0.06 & 1 & & & & & & \\
\hline (7) High network res. rating & $0.17^{*}$ & $0.27 *$ & -0.09 & 0.08 & 0.07 & -0.06 & 1 & & & & & \\
\hline (8) Boards per gen. partner & 0.12 & 0.10 & -0.06 & $0.46^{*}$ & $0.25 *$ & 0.01 & 0.05 & 1 & & & & \\
\hline (9) Corporate VC & $-0.32 *$ & 0.02 & 0.02 & -0.07 & -0.06 & -0.06 & -0.07 & $-0.23 *$ & 1 & & & \\
\hline (10) Angel investor & -0.10 & $-0.17 *$ & -0.04 & $-0.24 *$ & -0.05 & $0.24 *$ & -0.02 & -0.21 & -0.06 & 1 & & \\
\hline (11) Financing offered & -0.05 & $0.73 *$ & $0.21 *$ & 0.15 & $-0.17 *$ & $-0.26^{*}$ & $0.33 *$ & -0.02 & -0.10 & $-0.19 *$ & 1 & \\
\hline (12) Equity taken threshold & 0.13 & $-0.22 *$ & -0.08 & 0.11 & $0.24 *$ & -0.07 & 0.03 & 0.17 & -0.10 & $-0.23 *$ & 0.09 & 1 \\
\hline
\end{tabular}




\section{Table IV \\ Univariate Difference in Means Tests}

Panel A describes difference in means tests for accepted versus declined financing offers among offers received by start-ups with more than one Series A financing offer. The measure pre-money valuation is the product of the number of outstanding shares before the Series A round and the share price before the financing round (in \$M). The measure normalized industry deal experience is a dummy variable equal to 1 if the number of deals the $\mathrm{VC}$ has previously funded in the target start-up's industrial segment per years of operation places the VC above the sample median. The measure normalized funds raised is a dummy variable equal to 1 if the number of prior funds (excluding buyout funds) the VC has raised per number of years of operation places the VC above the sample median. The measure industry reputation rank is the rank (a ranking of seven being first best, with lower values indicating lower reputation) of VC reputation in the start-up's industrial segment among received offers, as rated by the entrepreneur. The measure high network resources rating is a dummy equal to 1 if a VC firm received the maximum Likert-scale measure (of 5) in at least one of the following entrepreneur-rated VC network resources: Recruiting resources, contacts with customers and suppliers, or contacts with investment bankers. Panel B describes conditional means of relative valuation offered, the offered pre-money valuation to a start-up relative to the highest offered valuation received by that start-up, and equality of means tests for the upper and lower halves (divided at the median) of normalized industry deal experience, normalized funds raised, industry reputation rank, and high network resources rating.

\begin{tabular}{lccc}
\hline \multicolumn{4}{c}{ Panel A: Difference in means tests } \\
\hline \multicolumn{4}{c}{} \\
\hline & Offer accepted & Offer not accepted & $t$-stat: equal means \\
\hline Pre-money valuation & 17.733 & 22.090 & 0.764 \\
Normalized industry deal exp. & 3.844 & 2.810 & -1.282 \\
Normalized funds raised & 0.667 & 0.515 & $-1.771^{*}$ \\
Industry reputation rank & 6.588 & 5.546 & $-5.711^{* * *}$ \\
High network resources rating & 0.549 & 0.371 & $-2.093^{* *}$ \\
\hline
\end{tabular}

\begin{tabular}{|c|c|c|c|}
\hline \multicolumn{4}{|c|}{ Panel B: Conditional means of relative valuation offered } \\
\hline & Top half & Bottom half & $t$-stat: equal means \\
\hline \multicolumn{4}{|c|}{ Normalized industry deal exp. } \\
\hline \multirow{7}{*}{ Relative valuation offered } & 0.812 & 0.844 & 0.880 \\
\hline & \multicolumn{3}{|c|}{ Normalized VC funds raised } \\
\hline & 0.820 & 0.834 & 0.397 \\
\hline & \multicolumn{3}{|c|}{ Industry reputation rank } \\
\hline & 0.798 & 0.843 & 1.233 \\
\hline & \multicolumn{3}{|c|}{ High network resources rating } \\
\hline & 0.804 & 0.842 & 1.070 \\
\hline
\end{tabular}

$*, * *$, or $* * *$ indicate statistical significance at the $10 \%, 5 \%$, or $1 \%$ level, respectively. 


\section{Table V \\ VC Offer Acceptance Logit Regressions}

This table shows start-up fixed-effects logit regressions on a sample of 148 offers across 51 start-ups receiving multiple Series A financing offers. Regression coefficients are reported, with standard errors in parentheses below. The dependent variable, $V C$ offer accepted equals 1 if a financing offer was taken and 0 otherwise. The measure high industry deal experience is a dummy variable equal to 1 if the number of deals the $\mathrm{VC}$ has previously funded in the target start-up's industrial segment places the $\mathrm{VC}$ above the sample median. The measure relative valuation offered is the offered pre-money valuation to a start-up relative to the highest offered valuation received by that start-up. The measure high network resources rating is a dummy equal to 1 if a $\mathrm{VC}$ firm received the maximum Likert-scale measure (of 5) in at least one of the following entrepreneur-rated VC network resources: Recruiting resources, contacts with customers and suppliers, or contacts with investment bankers. The measure angel investor is a dummy variable equal to 1 if a financing offer is from an angel investor or angel group. The measure corporate $V C$ is a dummy equal to 1 if the $\mathrm{VC}$ is a corporate $\mathrm{VC}$. The measure $L$ financing offered is the natural logarithm of capital offered (in \$M) by the investor. The measure equity taken threshold is a dummy variable equal to 1 if the investor receives at least $30 \%$ of start-up equity (the median of the sample) as a result of the Series A financing offer.

\begin{tabular}{lccc}
\hline \multicolumn{3}{c}{$\begin{array}{c}\text { Dependent variable }=\text { VC offer accepted } \\
\mathrm{N}=148 \text { observations }\end{array}$} \\
\hline $\begin{array}{l}\text { Independent } \\
\text { Variables }\end{array}$ & $(5-1)$ & $(5-2)$ & $(5-3)$ \\
\hline High industry deal & $1.080^{* *}$ & $1.168^{* *}$ & $1.068^{* *}$ \\
experience & $(0.512)$ & $(0.532)$ & $(0.556)$ \\
High network resources & & $1.415^{* * *}$ \\
rating & & $(0.519)$ \\
Relative valuation offered & & 0.606 & 2.157 \\
& & $(0.887)$ & $(1.425)$ \\
Angel investor & & 0.558 \\
& & & $(0.799)$ \\
Corporate VC & & -0.450 \\
L financing offered & & $(0.972)$ \\
& & -0.329 \\
Equity taken threshold & & & $(0.593)$ \\
& & & 1.015 \\
Start-up fixed-effects & Yes & 0.070 & $(0.851)$ \\
Prob>chi2 & 0.028 & -48.962 & Yes \\
Log likelihood & -49.195 & & 0.016 \\
\hline
\end{tabular}

$* *$ or $* * *$ indicate statistical significance at the $5 \%$ or $1 \%$ level, respectively. 


\section{Table VI \\ Valuation Regressions}

This table shows the result of start-up fixed-effects OLS regressions on a sample of 148 offers across 51 start-ups receiving multiple Series A financing offers. The unit of observation is an offer to a start-up. Robust standard errors (adjusted for clustering by start-up firm) are reported (in parentheses). The dependent variable is relative valuation offered, the offered pre-money valuation to a start-up relative to the highest offered valuation received by that startup. The measure high industry deal experience is a dummy variable equal to 1 if the number of deals the $\mathrm{VC}$ has previously funded in the target start-up's industrial segment places the $\mathrm{VC}$ above the sample median. The measure $V C$ offer accepted equals 1 if a financing offer was taken and 0 otherwise. The measure high network resources rating is a dummy equal to 1 if a $\mathrm{VC}$ firm received the maximum Likert-scale measure (of 5) in at least one of the following entrepreneur-rated VC network resources: Recruiting resources, contacts with customers and suppliers, or contacts with investment bankers. The measure angel investor is a dummy variable equal to 1 if a financing offer is from an angel investor or angel group. The measure corporate $V C$ is a dummy equal to 1 if the $\mathrm{VC}$ is a corporate VC. The measure $L$ financing offered is the natural logarithm of capital offered (in $\$ \mathrm{M}$ ) by the investor. The measure equity taken threshold is a dummy variable equal to 1 if the investor receives at least $30 \%$ of start-up equity (the median of the sample) as a result of the Series A financing offer.

\begin{tabular}{|c|c|c|c|}
\hline \multirow[b]{2}{*}{$\begin{array}{l}\text { Independent } \\
\text { Variables }\end{array}$} & \multicolumn{3}{|c|}{$\begin{array}{l}\text { Dependent variable }=\text { Relative valuation offered } \\
\qquad N=148 \text { observations }\end{array}$} \\
\hline & $(6-1)$ & $(6-2)$ & $(6-3)$ \\
\hline $\begin{array}{l}\text { High industry deal } \\
\text { experience }\end{array}$ & $\begin{array}{l}-0.135^{* *} \\
(0.057)\end{array}$ & $\begin{array}{l}-0.144 * * \\
(0.060)\end{array}$ & $\begin{array}{l}-0.098 * * * \\
(0.036)\end{array}$ \\
\hline $\begin{array}{l}\text { High network resources } \\
\text { rating }\end{array}$ & & & $\begin{array}{l}-0.048 \\
(0.045)\end{array}$ \\
\hline VC offer accepted & & $\begin{array}{c}0.026 \\
(0.050)\end{array}$ & $\begin{array}{c}0.041 \\
(0.032)\end{array}$ \\
\hline Angel investor & & & $\begin{array}{l}-0.021 \\
(0.084)\end{array}$ \\
\hline Corporate VC & & & $\begin{array}{c}0.016 \\
(0.110)\end{array}$ \\
\hline L financing offered & & & $\begin{array}{l}0.261 * * * \\
(0.054)\end{array}$ \\
\hline Equity taken threshold & & & $\begin{array}{l}-0.291 * * * \\
(0.067)\end{array}$ \\
\hline Start-up fixed-effects & Yes & Yes & Yes \\
\hline Constant & $\begin{array}{l}0.885^{* * * *} \\
(0.025)\end{array}$ & $\begin{array}{l}0.880 * * * \\
(0.027)\end{array}$ & $\begin{array}{l}0.632 * * * \\
(0.090)\end{array}$ \\
\hline Adj. R-Squared & 0.098 & 0.094 & 0.460 \\
\hline
\end{tabular}

$* *$ or $* * *$ indicate statistical significance at the $5 \%$ or $1 \%$ level, respectively. 


\section{Table VII Offer Acceptance Robustness Regressions}

This table reports robustness checks on VC offer acceptance regressions. Fixed effects logit regressions of VC offer accepted, a dummy equal to 1 if an offer was accepted by the entrepreneur, on the sample of multiple offers are found in columns 1 to 3 . The measure high industry deal experience is a dummy variable equal to 1 if the number of deals the VC has previously funded in the target start-up's industrial segment places the VC above the sample median. The measure high normalized funds raised is a dummy variable equal to 1 if the number of prior funds (excluding buyout funds) the VC has raised per years of operation places the VC above the sample median. The measure industry reputation rank is the rank (a ranking of 7 being first best, with lower values indicating lower reputation) of $\mathrm{VC}$ reputation among offers received, as rated by the entrepreneur. The measure high network resources rating is a dummy equal to 1 if a $\mathrm{VC}$ firm received the maximum Likert-scale measure (of 5) in at least one of the following entrepreneur-rated VC network resources: recruiting resources, contacts with customers and suppliers, or contacts with investment bankers. The measure boards per general partner is the average number of boards of directors per general venture capital partner. The measure angel investor is a dummy variable equal to 1 if a financing offer is from an angel investor or angel group. The measure relative valuation offered is the offered pre-money valuation to a start-up relative to the highest offered valuation received by that start-up. The measure corporate $V C$ is a dummy equal to 1 if the VC is a corporate VC. The measure $L$ financing offered is the natural logarithm of capital offered (in $\$ \mathrm{M}$ ) by the investor. The measure equity taken threshold is a dummy variable equal to 1 if the investor receives at least $30 \%$ of start-up equity (the median of the sample) as a result of the Series A financing offer. Columns 4 and 5 show start-up fixed-effects Heckman sample selection probits on the entire sample of 246 offers across 149 start-ups receiving Series A financing offers. A first stage selection (probit) equation determines the likelihood that a start-up receives multiple financing offers (multiple offer). The estimated covariates are: L initial employees, the natural logarithm of the pre-Series A number of start-up employees; zero patents, a dummy equal to 1 if the start-up does not have assigned patents; and dummy variables equal to 1 for each of the following industrial segments: Internet (infrastructure, retail, and service), health sciences (biotechnology and medical devices), and computers (software and hardware). Dummies for years of Series A investment (1998, 1999, and 2000) are also included. The term rho is the correlation between error terms of the selection and primary equations; lamba is the inverse Mill's ratio.

Dependent variable $=$ VC offer accepted

\begin{tabular}{|c|c|c|c|c|c|}
\hline \multirow[b]{2}{*}{ Independent variables } & \multicolumn{3}{|c|}{$\begin{array}{c}\text { FE Logits } \\
\text { Multiple-offers sample }(\mathrm{N}=148)\end{array}$} & \multicolumn{2}{|c|}{$\begin{array}{c}\text { FE Heckman linear prob models } \\
\text { Entire sample }(\mathrm{N}=246)\end{array}$} \\
\hline & $(7-1)$ & $(7-2)$ & $(7-3)$ & $(7-4)$ & $(7-5)$ \\
\hline High industry deal experience & & & $\begin{array}{l}1.070^{* *} \\
(0.555)\end{array}$ & $\begin{array}{l}0.328^{* * *} \\
(0.120)\end{array}$ & $\begin{array}{l}0.287^{* *} \\
(0.119)\end{array}$ \\
\hline High normalized funds raised & $\begin{array}{r}0.725^{*} \\
(0.437)\end{array}$ & & & & \\
\hline Industry reputation rank & & $\begin{array}{l}1.097^{* * *} \\
(0.312)\end{array}$ & & & \\
\hline High network resources rating & $\begin{array}{l}1.428 * * * \\
(0.518)\end{array}$ & $\begin{array}{l}1.072 * * * \\
(0.547)\end{array}$ & & & $\begin{array}{l}0.375^{* * * *} \\
(0.104)\end{array}$ \\
\hline $\begin{array}{l}\text { Boards per general } \\
\text { partner }\end{array}$ & & & $\begin{array}{c}0.000 \\
(0.001)\end{array}$ & & \\
\hline Relative valuation offered & $\begin{array}{c}1.049 \\
(1.360)\end{array}$ & $\begin{array}{l}4.012 * * \\
(1.779)\end{array}$ & $\begin{array}{l}1.673 \\
(1.385)\end{array}$ & & $\begin{array}{r}0.499 * \\
(0.277)\end{array}$ \\
\hline Angel investor & $\begin{array}{c}0.536 \\
(0.792)\end{array}$ & $\begin{array}{l}1.314 \\
(0.864)\end{array}$ & $\begin{array}{c}0.642 \\
(0.811)\end{array}$ & & $\begin{array}{c}0.200 \\
(0.186)\end{array}$ \\
\hline Corporate VC & $\begin{array}{l}-0.614 \\
(0.920)\end{array}$ & $\begin{array}{l}-0.795 \\
(1.137)\end{array}$ & $\begin{array}{l}-0.395 \\
(0.969)\end{array}$ & & $\begin{array}{l}-0.051 \\
(0.186)\end{array}$ \\
\hline L financing offered & $\begin{array}{l}-0.009 \\
(0.574)\end{array}$ & $\begin{array}{l}-1.242 * \\
(0.757)\end{array}$ & $\begin{array}{l}-0.370 \\
(0.600)\end{array}$ & & $\begin{array}{l}-0.039 \\
(0.113)\end{array}$ \\
\hline Equity taken threshold & $\begin{array}{c}0.778 \\
(0.840)\end{array}$ & $\begin{array}{l}1.453 \\
(1.127)\end{array}$ & $\begin{array}{l}1.230 \\
(0.800)\end{array}$ & & $\begin{array}{c}0.220 \\
(0.154)\end{array}$ \\
\hline Log likelihood & -43.522 & -35.754 & -47.197 & -249.406 & -240.326 \\
\hline Rho & & & & $\begin{array}{l}-0.000 \\
(1.630)\end{array}$ & $\begin{array}{l}-0.109 \\
(0.709)\end{array}$ \\
\hline Lambda & & & & $\begin{array}{l}-0.000 \\
(0.735)\end{array}$ & $\begin{array}{l}-0.046 \\
(0.304)\end{array}$ \\
\hline
\end{tabular}

$*, * *$, or $* * *$ indicate statistical significance at the $10 \%, 5 \%$, or $1 \%$ level, respectively.

Heckman first stage (selection) equation (SE in parentheses): Multiple offer $=-0.262(0.356)+0.147(0.108)$ L init. emp. 0.461 (0.208) Zero patents +0.663 (0.251) Internet industry $+0.278(0.362)$ Health science industry $+0.315(0.288)$

Computer industry - 0.199 (0.303) Year 1998 - 0.080 (0.266) Year $1999+0.292$ (0.262) Year 2000 


\section{Table VIII Valuation Robustness Regressions}

This table reports robustness checks on relative valuation offered, the offered pre-money valuation to a start-up relative to the highest offered valuation received by that start-up. Fixed effects OLS analysis (with robust standard errors) on the sample of multiple offers is reported in columns 1 to 3 . The measure high industry deal experience is a dummy variable equal to 1 if the number of deals the VC has previously funded in the target start-up's industrial segment places the VC above the sample median. The term high normalized funds raised is a dummy variable equal to 1 if the number of prior funds (excluding buyout funds) the VC has raised per years of operation places the VC above the sample median. The measure industry reputation rank is the rank (a ranking of 7 being first best, with lower values indicating lower reputation) of $\mathrm{VC}$ reputation among offers received, as rated by the entrepreneur. The measure $V C$ offer accepted, a dummy equal to 1 if an offer was accepted by the entrepreneur. The measure high network resources rating is a dummy equal to 1 if a VC firm received the maximum Likert-scale measure (of 5) in at least one of the following entrepreneur-rated VC network resources: Recruiting resources, contacts with customers and suppliers, or contacts with investment bankers. The measure boards per general partner is the number of boards of directors per general venture capital partner. The measure angel investor is a dummy variable equal to 1 if a financing offer is from an angel investor or angel group. The measure corporate $V C$ is a dummy equal to 1 if the VC is a corporate VC. The measure $L$ financing offered is the natural logarithm of capital offered (in $\$ \mathrm{M}$ ) by the investor. The measure equity taken threshold is a dummy variable equal to 1 if the investor receives at least $30 \%$ of start-up equity (the median of the sample) as a result of the Series A financing offer. Columns 4 and 5 show start-up fixed effects Heckman sample selection probits on the entire sample of 246 offers across 149 start-ups receiving Series A financing offers. A first stage selection (probit) equation determines the likelihood that a start-up receives multiple financing offers (multiple offer). The estimated covariates are: L initial employees, the natural logarithm of the pre-Series A number of start-up employees; zero patents, a dummy equal to 1 if the start-up does not have assigned patents; and dummy variables equal to 1 for each of the following industrial segments: Internet (infrastructure, retail, and service), health sciences (biotechnology and medical devices), and computers (software and hardware). Dummies for years of Series A investment (1998, 1999, and 2000) are also included. The term rho is the correlation between error terms of the selection and primary equations; lamba is the inverse Mill's ratio.

\begin{tabular}{|c|c|c|c|c|c|}
\hline \multirow[b]{3}{*}{ Independent variables } & \multicolumn{5}{|c|}{ Dependent variable $=$ Relative valuation offered } \\
\hline & \multicolumn{3}{|c|}{$\begin{array}{c}\text { FE OLS regressions } \\
\text { Multiple-offers sample }(\mathrm{N}=148)\end{array}$} & \multicolumn{2}{|c|}{$\begin{array}{c}\text { FE Heckmans } \\
\text { Entire sample }(\mathrm{N}=246)\end{array}$} \\
\hline & $(8-1)$ & $(8-2)$ & $(8-3)$ & $(8-4)$ & $(8-5)$ \\
\hline High industry deal experience & & & $\begin{array}{l}-0.073 * \\
(0.039)\end{array}$ & $\begin{array}{l}-0.135^{* * *} \\
(0.044)\end{array}$ & $\begin{array}{l}-0.098 * * * \\
(0.034)\end{array}$ \\
\hline High normalized funds raised & $\begin{array}{c}0.061 \\
(0.042)\end{array}$ & & & & \\
\hline Industry reputation rank & & $\begin{array}{l}-0.041 * * \\
(0.018)\end{array}$ & & & \\
\hline High network resources rating & $\begin{array}{l}-0.056 \\
(0.053)\end{array}$ & $\begin{array}{l}-0.038 \\
(0.047)\end{array}$ & & & $\begin{array}{l}-0.048 \\
(0.031)\end{array}$ \\
\hline $\begin{array}{l}\text { Boards per general } \\
\text { partner }\end{array}$ & & & $\begin{array}{l}-0.000^{*} \\
(0.000)\end{array}$ & & \\
\hline VC offer accepted & $\begin{array}{c}0.056 \\
(0.035)\end{array}$ & $\begin{array}{l}0.046^{*} \\
(0.034)\end{array}$ & $\begin{array}{c}0.031 \\
(0.033)\end{array}$ & & $\begin{array}{r}0.041^{*} \\
(0.024)\end{array}$ \\
\hline Angel investor & $\begin{array}{c}0.114 \\
(0.162)\end{array}$ & $\begin{array}{l}-0.044 \\
(0.083)\end{array}$ & $\begin{array}{l}-0.064 \\
(0.072)\end{array}$ & & $\begin{array}{l}-0.021 \\
(0.054)\end{array}$ \\
\hline Corporate VC & $\begin{array}{c}0.024 \\
(0.093)\end{array}$ & $\begin{array}{c}0.029 \\
(0.114)\end{array}$ & $\begin{array}{l}-0.014 \\
(0.112)\end{array}$ & & $\begin{array}{l}0.016 \\
(0.055)\end{array}$ \\
\hline L financing offered & $\begin{array}{l}0.355^{* * *} \\
(0.082)\end{array}$ & $\begin{array}{l}0.276^{* * *} \\
(0.050)\end{array}$ & $\begin{array}{l}0.287 * * * \\
(0.046)\end{array}$ & & $\begin{array}{l}0.261 * * * \\
(0.028)\end{array}$ \\
\hline Equity taken threshold & $\begin{array}{l}-0.290^{* * *} \\
(0.074)\end{array}$ & $\begin{array}{l}-0.283 * * * \\
(0.071)\end{array}$ & $\begin{array}{l}-0.306^{* * * *} \\
(0.065)\end{array}$ & & $\begin{array}{l}-0.291 * * * \\
(0.039)\end{array}$ \\
\hline Constant & $\begin{array}{l}0.370 * * * \\
(0.132)\end{array}$ & $\begin{array}{l}0.793 * * * \\
(0.148)\end{array}$ & $\begin{array}{l}0.555^{* * *} \\
(0.071)\end{array}$ & & \\
\hline Adj. R squared/LL & 0.593 & 0.471 & 0.497 & -100.045 & -57.314 \\
\hline Rho & & & & $\begin{array}{c}0.000 \\
(0.677)\end{array}$ & $\begin{array}{l}-0.000 \\
(0.960)\end{array}$ \\
\hline Lambda & & & & $\begin{array}{c}0.000 \\
(0.111)\end{array}$ & $\begin{array}{l}-0.000 \\
(0.118)\end{array}$ \\
\hline
\end{tabular}

$*, * *$, or $* * *$ indicate statistical significance at the $10 \%, 5 \%$, or $1 \%$ level, respectively.

Heckman first stage (selection) equation (SE in parentheses): Multiple offer $=-0.262(0.356)+0.147(0.108)$ L init. emp. -0.461 (0.208) Zero patents +0.663 (0.251) Internet industry $+0.278(0.362)$ Health science industry $+0.315(0.288)$ Computer industry 0.199 (0.303) Year $1998-0.080$ (0.266) Year $1999+0.292(0.262)$ Year 2000 


\section{Table IX \\ Cross-Sectional Regressions}

This table reports OLS regressions, and is based on a sample of accepted Series A financing offers of 149 start-ups. The unit of observation is an offer to a start-up. The dependent variable is L pre-money valuation, the natural logarithm of the product of the number of outstanding shares before the Series A round and the share price before the financing round (in \$M). The measure high industry deal experience is a dummy variable equal to 1 if the number of deals the VC has previously funded in the target start-up's industrial segment places the VC above the sample median in this category. The measure boards per general partner is the number of boards of directors per general venture capital partner. The measure angel investor is a dummy variable equal to 1 if a financing offer is from an angel investor or angel group. The measure corporate $V C$ is a dummy equal to 1 if the $\mathrm{VC}$ is a corporate $\mathrm{VC}$. The measure $L$ financing offered is the natural logarithm of capital offered (in $\$ \mathrm{M}$ ) by the investor. The measure equity taken threshold is a dummy variable equal to 1 if the investor receives at least $30 \%$ of start-up equity (the median of the sample) as a result of the Series A financing offer. The measure $L$ initial employees is the natural $\log$ of the number of employees prior to receiving the Series A round. The measure zero patents is a dummy equal to 1 if the start-up does not have assigned patents. The measure industry effects represent a collection of indicator variables for the Internet (infrastructure, retail, and service), health sciences (biotechnology and medical devices), and computers (software and hardware) sectors (the communications industry is the excluded industry segment). Years of Series A investment dummies (1998, 1999, and 2000) are also included.

\begin{tabular}{|c|c|c|c|}
\hline \multirow{2}{*}{ Independent variables } & \multicolumn{3}{|c|}{$\begin{array}{l}\text { Dependent variable }= \\
\text { L pre-money valuation }\end{array}$} \\
\hline & $(9-1)$ & $(9-2)$ & $(9-3)$ \\
\hline \multicolumn{4}{|l|}{ VC characteristics } \\
\hline High industry deal experience & $\begin{array}{l}0.478^{* * * *} \\
(0.145)\end{array}$ & $\begin{array}{l}0.425^{* * *} \\
(0.132)\end{array}$ & $\begin{array}{c}0.058 \\
(0.081)\end{array}$ \\
\hline Boards per general partner & & & $\begin{array}{l}-0.000 \\
(0.000)\end{array}$ \\
\hline Angel investor & & & $\begin{array}{c}0.033 \\
(0.113)\end{array}$ \\
\hline Corporate VC & & & $\begin{array}{l}-0.056 \\
(0.173)\end{array}$ \\
\hline L financing offered & & & $\begin{array}{l}0.663 * * * \\
(0.039)\end{array}$ \\
\hline Equity taken threshold & & & $\begin{array}{l}-0.753^{* * *} \\
(0.072)\end{array}$ \\
\hline \multicolumn{4}{|l|}{ Start-up characteristics } \\
\hline L initial employees & & $\begin{array}{l}0.514 * * * \\
(0.081)\end{array}$ & $\begin{array}{l}0.189 * * * \\
(0.050)\end{array}$ \\
\hline Zero patents & & $\begin{array}{l}-0.223 \\
(0.154)\end{array}$ & $\begin{array}{l}-0.165^{* *} \\
(0.083)\end{array}$ \\
\hline Industry effects & & Yes & Yes \\
\hline Year 1998 & & $\begin{array}{c}0.028 \\
(0.215)\end{array}$ & $\begin{array}{l}-0.157 \\
(0.116)\end{array}$ \\
\hline Year 1999 & & $\begin{array}{c}0.263 \\
(0.194)\end{array}$ & $\begin{array}{l}-0.075 \\
(0.105)\end{array}$ \\
\hline Year 2000 & & $\begin{array}{l}0.466^{* *} \\
(0.197)\end{array}$ & $\begin{array}{l}0.061 \\
(0.107)\end{array}$ \\
\hline Constant & $\begin{array}{l}1.959 * * * \\
(0.084)\end{array}$ & $\begin{array}{l}0.828^{* * * *} \\
(0.253)\end{array}$ & $\begin{array}{l}1.563^{* * *} \\
(0.162)\end{array}$ \\
\hline R-squared & 0.070 & 0.338 & 0.820 \\
\hline
\end{tabular}

$*, * *$, or $* * *$ indicate statistical significance at the $10 \%, 5 \%$, or $1 \%$ level, respectively. 